Makale Geliș | Received: 24.01.2021

Makale Kabul | Accepted: 19.02.2021

DOI: 10.18795 /gumusmaviatlas. 867540

Mavi Atlas, 9(1)2021: 275-294

Araştırma Makalesi | Research Article

\begin{abstract}
Nursal KUMAŞ
Öğr. Gör. Dr.| Lect. Dr.

Bursa Uludağ Üniversitesi, Atatürk İlkeleri ve İnkılap Tarihi Bölümü, Bursa-TÜRKİYE

Bursa Uludag University, Department of Atatürk's Principles and History of Turkish Revolution, Bursa-TURKEY

ORCID: 0000-0002-6554-5007

nkumas@uludag.edu.tr
\end{abstract}

\title{
Atatürk Döneminde Kütahya’da Eğitim İstatistiklerinin Analizi
}

\section{$\ddot{O} z$}

$\mathrm{Bu}$ çalışmada Kütahya ilinin eğitim öğretim yapısı örgün ve yaygın eğitim kapsamında Atatürk dönemiyle sınırlandırılarak incelendi. Çalışmada özellikle öğrenci, öğretmen, okul ve okur-yazar verileri üzerinde duruldu. Kütahya iliyle ilgili nüfus ve eğitim verileri Türkiye İstatistik Kurumunun ve Maarif Vekâletinin istatistiklerinden elde edildi. Ayrıca Cumhuriyet Arșivi Belgeleri (BCA), Türkiye Cumhuriyeti Devlet Salnameleri, CHP’nin yayınladığı istatistik ve talimatnameler ve Kütabya gazetesinden yararlanıldı. Sayısal veriler tablo ve grafik aracılığıyla metne aktarılıp yorumlandı.

Kütahya ili genelinde 1927 y1lında okuma-yazma oranı \%4,95 iken bu oran 1935 yılında artıș göstererek \%11,54 oldu. Okuma-yazma oranındaki bu artışa rağmen Kütahya 1927-1935 yılları arasında Türkiye ortalamalarının altında kaldı. Kütahya ilinde örgün eğitim kurumları olarak anaokulu, ilkokul, ortaokul ve lise bulunmaktaydı. 1923-1924 dönemi itibarıyla il merkezinde ve Uşak ilçesinde birer anaokulunun faaliyet gösterdiği belirlendi. 1927-1928 eğitim öğretim y1lında il genelinde 124 ilkokul varken 1932-1933 eğitim öğretim yılında bu rakam 154'e kadar yükseldi. Dönem içinde Kütahya şehir merkezinde ve Uşak ilçesinde birer ortaokul mevcuttu. Kütahya il merkezinde bulunan ortaokul 1933 yılında liseye dönüştürüldü fakat aynı yıl okulda çıkan yangın nedeniyle eğitim öğretime ara verildi. Kütahya Lisesi restore edildikten sonra 1937-1938 eğitim öğretim yıllnda yeniden açıldı. İl merkezi ve Uşak ilçesinde birer imam hatip okulu vardı. Ayrıca il merkezinde sanayi zirai okulu eğitim öğretim faaliyetinde bulunmaktaydı. Şehirde yaygin öğretim kapsamında millet mektepleri ve Kütahya Halkevi Halk Dershaneleri ve Kursları Şubesi ön plandaydı. Simav Halkevinin ilgili şubeleri, şehirde yerel düzeyde yayım yapan Kütabya gazetesi ve iki kütüphane eğitim öğretimi destekler nitelikte faaliyet göstermekteydi.

Anahtar Kelimeler: Kütahya, Eğitim, Türk Eğitim Tarihi, Cumhuriyet Dönemi

\section{Analysis of Education Statistics in Kütahya During the Atatürk Period}

\begin{abstract}
In this study, the education structure of Kütahya province was examined within the scope of formal and non-formal education by limiting it to the Atatürk Period. The study focused on student, teacher, school and literate data. Population and education data for Kütahya province were obtained from Turkey Statistical Institute and Ministry of Education statistics. In addition, Republic Archives' documents (BCA), the Republic of Turkey Yearbooks, the statistics and instructions published by the CHP and the Kütabya newspaper were also used. Numerical data were transferred to the text via tables and graphics and interpreted.

While the literacy rate was 4,95\% in 1927 throughout the province of Kütahya, this rate increased in 1935 and became $11,54 \%$. Despite this increase in literacy rate, Kütahya remained below the averages of Turkey during 1927-1935. There were kindergartens, primary schools, secondary schools and high schools as formal education institutions in the province of Kütahya. As of 1923-1924 academic year, it was determined that there was one kindergarten in the city center and in the town of Uşak. While there were 124 primary schools throughout the province in the 1927-1928 academic year, this figure rose to 154 in the 1932-1933 academic year. During the period, there was a secondary school in Kütahya city center and Uşak district. The secondary school in the city center of Kütahya was converted into a high school in 1933, but education was interrupted due to the fire that broke out in the school in the same year. After Kütahya High School was restored, it was reopened in the 1937-1938 academic year. There were imam and hatip schools in the city center and in Uşak district. In addition, the industrial agricultural school in the city center was engaged in education. Nation schools and Kütahya Community Center Public Classrooms and Courses Branch were at the forefront within the scope of non-formal education in the city. The relevant branches of the Simav Community Center, the local newspaper Kütabya in the city, and the two libraries were all supporting education.
\end{abstract}

Keywords: Kütahya, Education, Turkish Education History, Republic Period 


\section{Giriş}

Kütahya tarihsel derinliği milattan önceki ylllara dayanan bir yerleşim yeridir. Şehir Hititlerden günümüze kadar pek çok uygarlığın hâkimiyeti altında kaldıktan sonra 1381 y1lında Osmanlı idaresine girdi (Varlık, 2002: 580). XIX. yüzyılda Osmanlı yöneticilerinin yaptıkları idari düzenlemeler çerçevesinde Anadolu eyaleti kuruldu ve Kütahya bu eyaletin merkezi konumuna getirildi. Şehrin gelissip bu statüyü kazanmasında bölgeden geçen ticari yolların varlığı yanında zengin maden yataklarına sahip oluşu önemli bir rol oynadı. 1841 yllinda eyalet uygulamasina son verilip Hudâvendigâr vilayeti kurulunca vilayetin merkezi Bursa'ya taşındı (Kepecioğlu, C. II, 2009: 77; C. III, 2009: 206). Bu yeni uygulama neticesinde Kütahya şehri, Kütahya sancağının merkez kazası oldu. 1907/1908 yılına göre sancağa bağlı diğer kazalar; Eskişehir, Uşak, Simav ve Gediz'di. Kütahya kazasına bağlı 419 köy ve sekiz nahiye vardı. Bu nahiyeler: Altuntaş, Emet (Ĕ̆rigöz), Ermudili (Armudili), Gireği, Gümüş, Tavşanlı ve Virancık'dı (Hudâvendigâr Vilâyeti Sâlnâme-i Resmîsi, 1325: 125). Şehir, Cumhuriyet Dönemi'ne kadar kaza konumunu korudu. Cumhuriyet Dönemi'nde Kütahya'ya il statüsü verilerek; Emet, Gediz, Simav, Tavşanlı ve Uşak ilçeleri bu ile bağlandı. Şehrin toplam nüfusu Grafik No: 1'deki rakamlara göre 1927 yllında 302.426 iken bu rakam sekiz y1llik süre sonunda \%14,96 oranında artış göstererek 1935 yllında 347.682'e ulaştı. Şehir merkezinin nüfusu da 69.479 iken \%22,48 oranında artarak 85.099 oldu. S.ehir genelindeki gayrimüslim sayıs1 1927 yılında 423 iken 1935 yılında bu sayı 75’e düştü (1927 Nüfus Sayımı, Fasikül I, 1929: LVI; 1935 Nüfus Sayım Kütabya, 1937: 109).

Grafik No: 11927 ve 1935 Nüfus Sayımı Verilerine Göre Kütahya İlinin Nüfusu

Kaynak: 1927 Nüfus Sayımı, Fasikül I, 1929: XII; 1935 Nüfus Sayımı Kütabya, 1937: 5

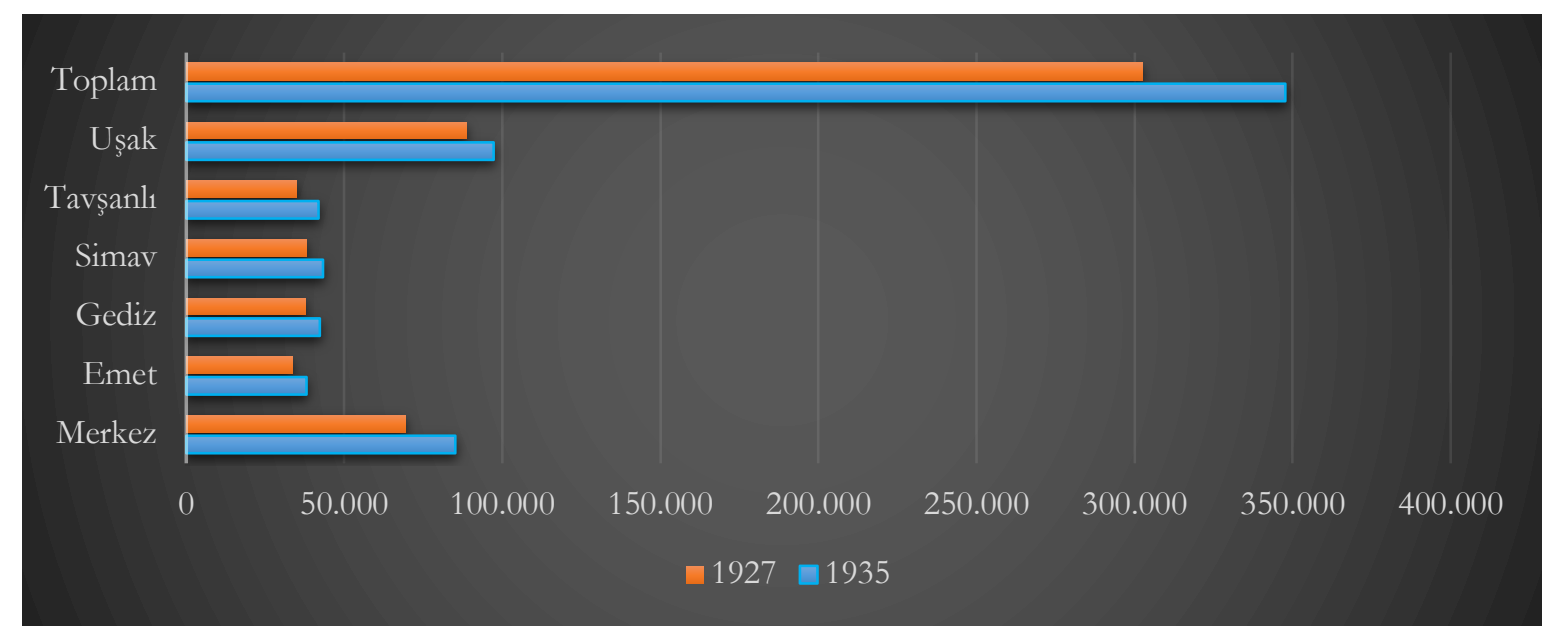

Cumhuriyet Dönemi'nin ilk yıllarında Kütahya merkezde, ilçe ve nahiye merkezlerinde Halk Fırkasının birer şubesi vardı. Merkez, Uşak, Gediz, Simav, Emet ve Tavşanlı ilçelerinde Türk Ocağı, Himaye-i Etfal, Hilal-i Ahmer ve Teyyare cemiyetlerinin birer şubeleri mevcuttu. Ayrıca Merkez ilçede Gençler Birliği ve Maluller Birliği cemiyetleri bulunmaktaydı. Uşak’ta Gençler Birliği, Esnaf Cemiyeti, Halıcılar Cemiyeti, İşçi ve Sanatkârlar Birliği ve Ergenekon İdman Yurdu mevcuttu. Merkez, Uşak, Gediz ve Simav ilçelerinde Ziraat Bankasının, Merkez ve Uşak ilçelerinde de Osmanlı Bankasının birer şubeleri vardı (1925-1926 Devlet Salnamesi, 1926: 798; 1926-1927 Devlet Salnamesi, 1927: 1076; 1927-1928 Devlet Salnamesi, 1928: 1152-1159). 1927 yll itibarıly il genelinde çeşitli sektörlerde olmak üzere toplam 1812 işletme ve bu işletmelerde çalışan 5451 çalışan mevcuttu. İl genelinde işletme sayısı $(953, \% 52,6)$ ve çalışan sayısı $(2156, \% 39,6)$ bakımından ilk sırayı tarım ve hayvancılık almaktaydı. Bu alanda çalışan sayısı 1935 yılında \%48,2'ye çıktı. Maden işletme ve dokumacıllk faaliyetleri de şehrin diğer önemli ekonomik sektörleri arasında gelmekteydi. 


\section{KUMAŞ, Nursal (2021). “Atatürk Döneminde Kütahya'da Eğitim İstatistiklerinin Analizi”, Mavi Atlas, 9(1): 275-294}

Dokumacıllk faaliyetleri şehrin genelinde etkiliydi fakat özellikle Uşak ilçesinde bu faaliyetler yoğunlaşmaktaydı (Sanayi Sayımı 1927, 1969: 43; 1935 Genel Nüfus Sayım Kütabya, 1937: 112). Şehir genelinde ayrıca 1927 yllı itibarıla 826 memur, 69 hâkim, 1093 askeri personel ve 205 PTT çalışanı görev yapmaktaydı (1927 Umumi Nüfus Sayımı, Fasikül I, 1929: XLII).

Kütahya merkezdeki çini atölyeleri ve yeni açlan tuğla ve kiremit fabrikasının yanında Uşak ilçesinde kurulan Türkiye'nin ilk şeker fabrikası şehrin sanayi alanındaki önemli değerleriydi. Söz konusu işletmeler Dr. Cevat Mazhar başkanlığında oluşturulan bir heyet tarafindan 7 Ekim 1928 tarihinde ziyaret edilerek çeşitli incelemelerde bulunuldu. Heyette Darülfünun Kimya bölümünde öğrenim gören 8’i erkek ve 10’u kız olmak üzere toplam 18 öğrenci yer almaktaydı (Kütabya, 69, 15 Ekim 1928: 9).

Kütahya merkezde ve kazalarda ayr1 ayrı olmak üzere maarif komisyonlar1 mevcuttu. Kütahya kazasındaki maarif komisyonunun başkanlığını Hacı Halil İbrahim Efendi yapmaktaydı. Komisyonun üyeleri şu isimlerden oluşmaktaydı: Mehmet Fevzi Efendi, Halil İbrahim Efendi, Hüseyin Efendi, Mehmet Rasih Efendi, Ali Cevat Efendi, Osman Bey, Şefik Bey ve kâtip ve sandık emini Osman Zühtü Efendi (Hudâvendigâr Vilâyeti Sâlnâme-i Resmîsi, 1325: 487).

Osmanlı Devleti'nin son dönemlerinde Batılllaşma çerçevesinde ülkenin birçok yerinde ibtidaiyye, rüşdiyye ve idadi olarak isimlendirilen Batı tarzı okullar açıldı. Müslim, gayrimüslim ve yabancıların açtıkları bu okulların yanında Osmanlı yönetiminin klasik eğitim kurumları olan mektep ve medreseler de eğitime devam etti. Böylece farklı uygulamaların olduğu bir eğitim sistemi oluştu. Kütahya sancağındaki eğitim uygulamaları da söz konusu sistemin bir parçasıdıd.

Kütahya sancağ1 genelinde 1907/1908 yıllarında 135 adet medrese ve bu medreselerde eğitim gören 4527 öğrenci vardı ${ }^{1}$. Bununla birlikte Kütahya kazasına bağlı 343 ibtidaiyyede 12.839 öğrenci ve sancak genelinde de 811 ibtidaiyyede 35.160 öğrenci eğitim görmekteydi. Aynı yıl Kütahya kazasına bağlı Gediz Rüşdiyyesinin 77, Simav Rüşdiyyesinin 49, Tavşanlı Rüşdiyyesinin de 41 öğrencisi vardı. Kütahya Mülkiye İdadisi 24 Ocak 1891 tarihinde açılmıştı. Nehari bir kurum olan Kütahya Mülki İdadisinin üç yılı rüşdiyye iki yılı da idadiydi. Okulun 1907/1908 eğitim öğretim yllındaki öğrenci sayısı 101'di. Sancak genelinde dördü Kütahya merkezde, biri Eskişehir'de, biri Uşak'ta ve biri de Gediz'de olmak üzere toplam yedi kütüphane ve bu kütüphanelerde toplam 3988 adet kitap bulunmaktayd1 (Hudâvendigâr Vilâyeti Sâlnâme-i Resmîsi, 1325: 329-335). Vilayet salnamelerinde Kütahya Merkez kazada Rum cemaatine ait biri ibtidaiyye diğeri de rüşdiyye derecesinde olmak üzere iki okul mevcuttu. İbtidaiyyenin ruhsatname tarihi 13 Kasım 1893 olup, öğrenci sayıs1 248 erkek ve 299 k1z olmak üzere toplam 547’ydi (Hudâvendigâr Vilâyeti Sâlnâme-i Resmîsi, 1321: 358-359). Rüşdiyyenin de ruhsatname tarihi 13 Ekim 1895'di. Okulun 178 erkek ve 25 kı olmak üzere toplam 203 öğrencisi vardı (Hudâvendigâr Vilâyeti Sâlnâme-i Resmîsi, 1316: 436437). Bu dönemde Kütahya kazasında yabancilara ait herhangi bir okul yoktu.

Cumhuriyet Dönemi'yle beraber TBMM tarafindan eğitim öğretim alanında önemli kanunlar çıkarıldı. 3 Mart 1924 Tevhid-i Tedrisat Kanunu'yla tüm eğitim öğretim faaliyetleri Maarif Vekâletine (Milli Eğitim Bakanlığı) bağlandı. Bu kanun aracilığıla merkezi bir programın uygulandığı laik, çağdaş ve karma eğitime geçildi. 1924 Anayasası'nın ilköğretimi zorunlu ve ücretsiz kılmasıyla birlikte tüm kız çocuklarının eğitim görmesinin önündeki engel kaldırıldı. 1 Kasım 1928 tarihinde Latin Harflerinin kabul edilmesi ve ardından millet mektepleri ve halk odalarının kurulmasıyla okuma-yazma faaliyetleri kolaylaştırılıp yaygınlaştırıldı. 19 Şubat 1932 tarihinde kurulan halkevleri, bünyelerinde açtıkları çeşitli kurslar arac1lığıly eğitim faaliyetlerinde önemli bir rol üstlendi. 18 Kasım 1933 tarihinde de Darülfünun kapatılarak yerine müfredatı değiştirilen

\footnotetext{
${ }^{1}$ İlgili salnamede ibtidai kelimesinin sehven idadi olarak yazıldığı belirlendi.
} 


\section{KUMAŞ, Nursal (2021). “Atatürk Döneminde Kütahya'da Eğitim İstatistiklerinin Analizi”, Mavi}

Atlas, 9(1): 275-294

İstanbul Üniversitesi açıldı. Böylelikle Atatürk döneminde eğitim öğretim alanında devrim niteliğinde kararlar alınıp uygulandı.

Bu araştırmada Kütahya ilinin Atatürk dönemindeki eğitim yapısının irdelenmesi amaçlandı. Bu bağlamda dönem içinde okulöncesi eğitim, temel eğitim, ortaöğretim, mesleki-teknik eğitim ve yaygın eğitim kurumları ele alındı. Söz konusu kurumların öğretmen ve öğrenci sayılarıyla ilgili tablolar oluşturularak yorumlanıp açıklanmaya çalışıldı. Kütahya iliyle yapılan literatür çalışmasında doğrudan Atatürk dönemi eğitim faaliyetleriyle ilgili yapılmış akademik bir çalışma tespit edilemedi. Kütahya Milli Eğitim Müdürlügü ve ildeki çeşitli okulların müdürleri tarafindan oluşturulup bir komisyon tarafindan hazırlanan Kütahya İli Cumhuriyet Öncesi ve Sonrası Eğitim (1998) isimli yayında şehrin çeşitli kültürel yönleri ve Osmanlı Devleti'nin son dönemlerinden günümüze kadar eğitim kurumlarıyla ilgili bilgiler yer almaktaydı. Çalışmada ayrıca Atatürk dönemiyle ilgili maarif verileri verilmiş fakat yeteri kadar yorumlanmamıştı. Kütahya Halkeviyle ilgili Havanur Şahin'in yaptığ1 Yüksek Lisans Tezi (Şahin, 2010: 37-41) ve Esra Sarıkoyuncu Değerli, Hasan Yapıcı'nın ortak kaleme almış oldukları çalışmalarda halkevi bünyesinde bir kitaplığın oluşturulduğu bilgisi verilmekte ve halk dershaneleri ve kurslar şubesinin faaliyetlerine değinilmekteydi (Değerli ve Yapıc1, 2018: 3-11). Buna karşın örgün eğitim kurumlarına ilişkin bir bilgiye yer verilmemiş, eğitim faaliyetleri sadece halkevi ekseninde değerlendirilmişti. Harun Yıldırım'ın, Kütahya şehrinin 19251928 yılları arasını tüm yönleriyle ele aldığı Yüksek Lisans Tezi çalışmasında eğitime de bir bölüm ayrılmış fakat sadece devlet salnameleri verileri dikkate alınarak üç yıllık dönem incelenmişti. (Yıldırım, 2017: 145-148). Bu dönemle ilgili yapılan bir diğer Yüksek Lisans Tezi de Kütahya Lisesi üzerine yapılan çalışmaydı. Bu çalışmada ağırlıklı olarak Kütahya Lisesinin Atatürk döneminden sonraki yıllar üzerinde yoğunlaşılmıştı.

Bu çalışmada Cumhuriyet Dönemi'nde Kütahya şehrinin eğitim yapısı tüm örgün ve yaygın eğitim kurumları dikkate alınarak irdelendi. Maarif istatistiklerinde yer almayan ders, ders programı, okulların temsil, konferans, spor vb. faaliyetleri üzerinde durulmadı. 1934-1937 yılları arasını içine alan maarif salnameleri veya bir başka istatistiki kaynak tespit edilemediği için bu döneme değinilemedi. Örgün ve yaygın eğitim kurumları okul, öğrenci ve öğretmen özelinde istatistiki veriler ışı̆̆ında tablo ve grafiklerle anlamlandırıldı. Çalışmada Atatürk dönemiyle ilgili Cumhuriyet Arşivi Belgeleri (BCA), Maarif Vekâletinin resmi yayınları, devlet salnameleri, 1927 ve 1935 yılı nüfus sayımı verileri bütüncül bir yaklaşım gözetilerek değerlendirildi ve sadece eğitim istatistiklerine dayalı bir çalışma ortaya konuldu.

\section{Okur-Yazarlik Durumu}

Tablo No: 11927 ve 1935 Yılı Nüfus Sayımlarına Göre Okur-Yazarlık Durumu

(1927 Umumi Nüfus Sayımı, Fasikül I, 1929: XLII; Fasikül III, 1929: 22-23; 1935 Genel Nüfus Sayımı Kütabya, 1937: 109; 1935 Genel Nüfus Sayımı, 1937: 204)

\begin{tabular}{|c|c|c|c|c|c|c|c|c|c|c|c|c|}
\hline \multirow{2}{*}{ Y11 } & \multicolumn{1}{|c|}{ Türkiye Geneli Okur-Yazar } & \multicolumn{4}{c|}{ Kütahya İl Geneli Okur-Yazar } \\
\cline { 2 - 13 } & Erkek & $\%$ & Kadın & $\%$ & Toplam & $\%$ & Erkek & $\%$ & Kadın & $\%$ & Toplam & $\%$ \\
\hline 1927 & 851.527 & 12,99 & 259.969 & 3,67 & 1.111 .496 & 8,61 & 13.152 & 9,45 & 1800 & 1,11 & 14.952 & 4,95 \\
\hline 1935 & 1.847 .183 & 23,27 & 670.695 & 8,16 & 2.517 .878 & 15,58 & 31.004 & 18,59 & 9103 & 4,99 & 40.107 & 11,54 \\
\hline \multicolumn{10}{|c|}{ Yedi Yaşı Üstündeki Nüfus } \\
\hline 1927 & $?$ & 17,42 & $?$ & 4,63 & $?$ & 10,58 & $?$ & 12,59 & $?$ & 1,37 & $?$ & 6,34 \\
\hline
\end{tabular}

Okur-yazarlık durumuyla ilgili veriler 1927 ve 1935 yılı nüfus sayımı sonuçlarından elde edildi. 1927 yılında Kütahya okur-yazar sayısı bakımından ülkedeki 63 il arasında erkeklerde 36, kadınlarda 31 ve toplamda 35. sıradaydı (1927 Umumi Nüfus Sayım, Fasikül III, 1929: 22-23). Tablo No: 1'deki verilerden anlaşılacağı üzere Kütahya okur-yazarlık açısından Türkiye ortalamalarının çok altındaydı. 
İl genelinde Türkçe dışında başka bir ana dili konuşan 420 erkekten 126's1 (1'i sadece okuma biliyor) ve 441 kadından yalnızca 37'si (1'i sadece okuma biliyor) okuma-yazma bilmekteydi. Toplam 861 kişide bu say1 163’tü (\%18,93). Okuma-yazma bilen bu kişilerden 85’i Kütahya şehir merkezinde ve 17'si de Uşak ilçesinde ikâmet etmekteydi.

Şehirdeki toplam 75 gayrimüslimden sadece 36's1 (\%48) (1'i sadece okuma biliyor) okumayazma biliyordu. Bu kişilerden 14'ü Kütahya şehir merkezinde, 11’i de Uşak ilçesinde ikâmet etmekteydi (1935 Genel Nüfus Sayım Kütahya, 1937: 121-122).

Tablo No: 2 Yaş Aralığına Göre Kütahya'da Okuma-Yazma Bilme Durumu (1935 Genel Nüfus Sayım Kütahya, 1937: 36-120)

\begin{tabular}{|c|c|c|c|c|c|c|}
\hline \multirow{2}{*}{$\begin{array}{c}\text { Yaş } \\
\text { Aralı̆g1 }\end{array}$} & \multicolumn{2}{|c|}{ Kütahya Genel } & \multicolumn{2}{c|}{ Kütahya Merkez } & \multicolumn{2}{c|}{ Uşak İlcsi } \\
\cline { 2 - 7 } & $\begin{array}{c}\text { Okuma-Yazma } \\
\text { Bilen }\end{array}$ & $\begin{array}{c}\text { Yalnız Okuma } \\
\text { Bilen }\end{array}$ & $\begin{array}{c}\text { Okuma-Yazma } \\
\text { Bilen }\end{array}$ & $\begin{array}{c}\text { Yalnız } \\
\text { Okuma Bilen }\end{array}$ & $\begin{array}{c}\text { Okuma-Yazma } \\
\text { Bilen }\end{array}$ & $\begin{array}{c}\text { Yalnız Okuma } \\
\text { Bilen }\end{array}$ \\
\hline $7-9$ & 3639 & 33 & 521 & 2 & 728 & 1 \\
\hline $10-14$ & 9479 & 44 & 1079 & 3 & 1387 & 1 \\
\hline $15-19$ & 5352 & 46 & 620 & 3 & 603 & 2 \\
\hline $20-24$ & 6469 & 57 & 1514 & 10 & 656 & 4 \\
\hline $25-29$ & 4793 & 55 & 884 & 8 & 672 & 9 \\
\hline $30-34$ & 3874 & 68 & 555 & 12 & 492 & 11 \\
\hline $35-39$ & 2663 & 51 & 463 & 9 & 410 & 7 \\
\hline $40-44$ & 1367 & 30 & 249 & 6 & 201 & 1 \\
\hline $45-49$ & 807 & 22 & 176 & 4 & 115 & 6 \\
\hline $50-54$ & 516 & 19 & 116 & 6 & 62 & 2 \\
\hline $55-59$ & 294 & 15 & 62 & 5 & 53 & 5 \\
\hline $60-64$ & 182 & 14 & 40 & 3 & 30 & 3 \\
\hline $65-69$ & 88 & 7 & 17 & 1 & 16 & 1 \\
\hline $70-74$ & 64 & 2 & 9 & - & 9 & - \\
\hline $75-79$ & 13 & - & 2 & - & 1 & - \\
\hline $80-84$ & 16 & - & 2 & - & 2 & - \\
\hline $85-89$ & 3 & - & 1 & - & - & - \\
\hline $90-94$ & 5 & 1 & 1 & - & 1 & - \\
\hline $95+$ & 3 & - & - & - & 1 & - \\
\hline Bilinmiyor & 14 & 2 & 4 & 72 & 5440 & 53 \\
\hline Toplam & 39.641 & 466 & 6315 & & & - \\
\hline
\end{tabular}

Tablo No: 2 verilerine göre; öğrenim çağındaki çocuklarla, 20-44 arasındaki yaş grubunun okuma-yazma bilme oranı diğer yaş gruplarına oranla daha yüksekti. Ülke genelinde açılan millet mekteplerinin bu yaş grubuna hitap etmesi söz konusu sonucu ortaya çıkarmaktaydı.

1935 yllinda Kütahya şehir merkezinde okuma-yazma bilen 4639 erkek bulunuyordu (23’ü sadece okuma biliyor). Bu rakam erkek nüfusun \%50,23'ünü oluşturuyordu. Başka bir ifadeyle her iki erkekten biri okuma-yazma bilmekteydi. Kadınlardan da 1748'i okuma-yazma biliyordu (49'u sadece okuma biliyor) ki bu rakam tüm kadın nüfusun beşte birine denk gelmekteydi. Şehir merkezinde erkek ve kadın olmak üzere toplamda okuma-yazma bilen sayıs1 6387 (72'si sadece okuma biliyor) olup merkez nüfusun $\% 35,91$ 'ini oluşturmaktaydı.

Uşak ilçesinde 3850 erkek (\%45,88) (31’i sadece okuma biliyor) ve 1643 kadın (\%17,91) (22'si sadece okuma biliyor) ve ilçe toplamında 5493 (\%31,27) kişi okuma-yazma bilmekteydi (1935 Genel Nüfus Saym Kütabya, 1937: 53).

Tablo No: 31935 Yılı Verilerine Göre İl Genelinde Yaş Gruplarına ve Cinsiyete Bağlı OkumaYazma Durumu (1935 Genel Nüfus Sayımı Kütabya, 1937: 120)

\begin{tabular}{|c|c|c|}
\hline Yaş & Erkekler & Kadınlar \\
\hline
\end{tabular}


KUMAŞ, Nursal (2021). “Atatürk Döneminde Kütahya'da Eğitim İstatistiklerinin Analizi”, Mavi Atlas, 9(1): 275-294

\begin{tabular}{|c|c|c|c|c|c|c|}
\hline Grupları & $\begin{array}{c}\text { Okuma-Yazma } \\
\text { Bilen }\end{array}$ & $\begin{array}{c}\text { Yalnız Okuma } \\
\text { Bilen }\end{array}$ & Toplam & $\begin{array}{c}\text { Okuma-Yazma } \\
\text { Bilen }\end{array}$ & $\begin{array}{c}\text { Yalnız Okuma } \\
\text { Bilen }\end{array}$ & Toplam \\
\hline $7-9$ & 2402 & 18 & 2420 & 1237 & 15 & 1252 \\
\hline $10-14$ & 6828 & 33 & 6861 & 2851 & 11 & 2862 \\
\hline $15-19$ & 4009 & 30 & 4039 & 1343 & 16 & 1359 \\
\hline $20-24$ & 5210 & 38 & 5248 & 1259 & 19 & 1278 \\
\hline $25-29$ & 3847 & 36 & 3883 & 946 & 19 & 965 \\
\hline $30-34$ & 3279 & 46 & 3325 & 595 & 22 & 617 \\
\hline $35-39$ & 2300 & 33 & 2333 & 363 & 18 & 381 \\
\hline $40-44$ & 1214 & 20 & 1234 & 153 & 10 & 163 \\
\hline $45-49$ & 722 & 19 & 741 & 85 & 3 & 88 \\
\hline $50-54$ & 478 & 16 & 494 & 38 & 3 & 41 \\
\hline $55-59$ & 269 & 7 & 276 & 25 & 8 & 33 \\
\hline $60-64$ & 154 & 14 & 168 & 28 & - & 28 \\
\hline $65-69$ & 77 & 6 & 83 & 11 & 1 & 12 \\
\hline $70-74$ & 54 & 2 & 56 & 10 & - & 10 \\
\hline $75-79$ & 11 & - & 11 & 2 & - & 2 \\
\hline $80-84$ & 6 & - & 6 & 10 & - & 10 \\
\hline $85-89$ & 3 & - & 3 & - & - & - \\
\hline $90-94$ & 4 & 1 & 5 & 1 & - & 1 \\
\hline $95+$ & 3 & - & 3 & - & - & - \\
\hline Bilinmiyor & 13 & 2 & 15 & 1 & - & 1 \\
\hline Toplam & 30.683 & 321 & 31.004 & 8958 & 145 & 9103 \\
\hline
\end{tabular}

Grafik No: 2 Kütahya İli Genelinde Cinsiyete Dayalı Okur-Yazar Durumu (Tablo No: 3 verilerine dayalı olarak hazırlandi.)

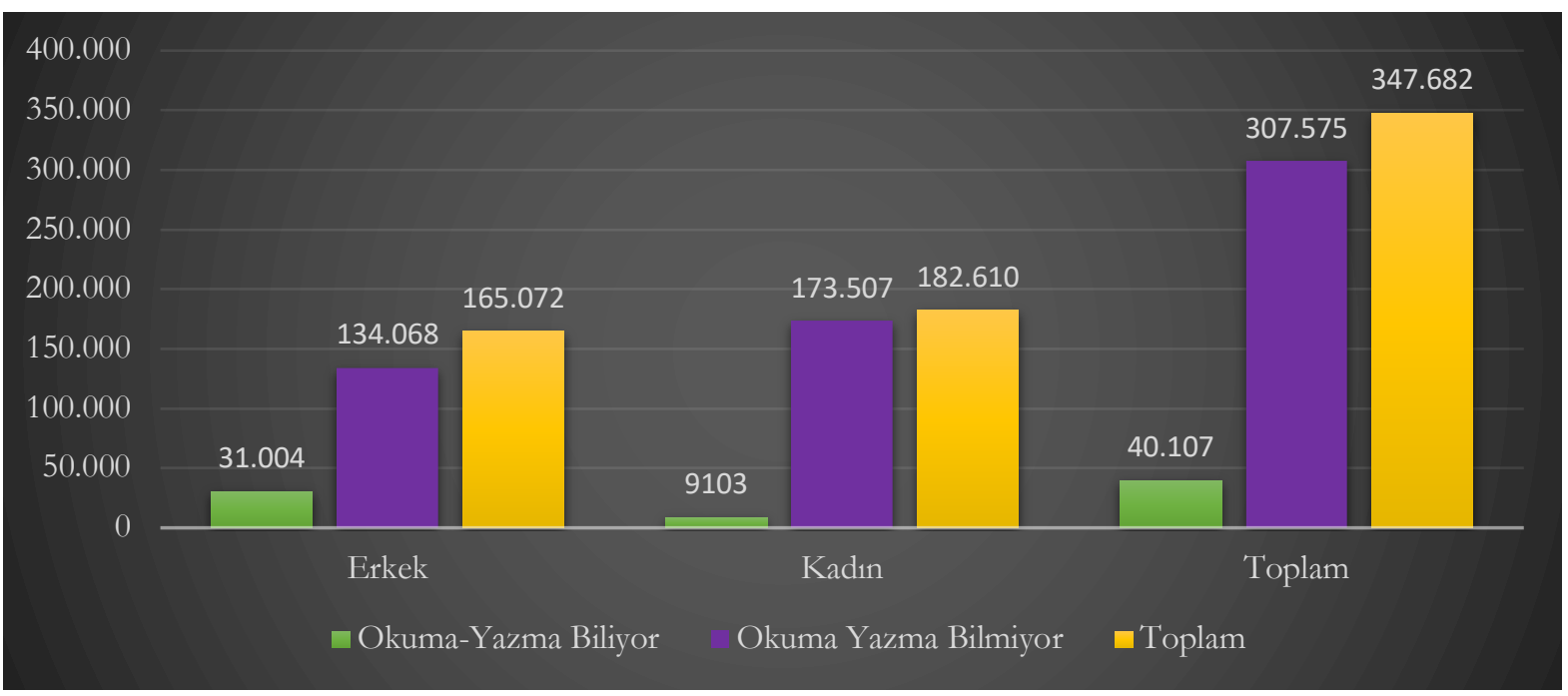

Tablo No: 3 ve Grafik No: 2'deki verilere göre; öğrenim çağındaki nüfus dikkate alınmadığında 20-24 yaş aralı̆̆ında erkeklerin ve kadınların okuma-yazma oranı en yüksek derecedeydi. Okuma-yazma bilen erkek nüfus içinde 7-19 yaş grubunda bulunan erkeklerin oranı \%42,32'ydi. Aynı yaş grubundaki kadın nüfus içinde kadınların okuma-yazma bilme oranı da \%60,12’ydi. Bu durumda erkeklerin okuma-yazmayı ağırlıklı olarak yaygın eğitim kurumlarında, kadınların da yine ağırlıklı olarak örgün eğitim kurumlarında öğrendiği söylenebilir. 7-19 yaş grubu içinde okula gitme oranı \%22,29'du (erkeklerde \%29,62; kadınlarda \%14,37’ydi) (1935 Genel Nüfus Sayım Kütabya, 1937: 120). Bu dönemde ilköğretimin zorunlu hale getirilmiş olmasına rağmen Kütahya ilinde yaklaşık beş çocuktan sadece bir tanesi okula gitmekteydi. Şehirde yeterli düzeyde 


\section{KUMAŞ, Nursal (2021). “Atatürk Döneminde Kütahya'da Eğitim İstatistiklerinin Analizi”, Mavi Atlas, 9(1): 275-294}

örgün eğitim kurumunun olmaması yanında bölge halkının eğitim öğretim faaliyetlerine yeterince önem vermemesi ve özellikle 1-3 kişilik küçük aile işletmelerinin yaygin oluşu bu sonucu ortaya çıkarmaktaydı (Sanayi Sayımı 1927, 1969: 56). Yaşın artışına bağlı olarak okuma-yazma bilme durumunun da azaldığı anlaşılmaktadır. Yaşlı nüfusta da aynı durum geçerliydi. Nitekim 65 yaş üstü dikkate alındığında 167 erkeğe karşılık 35 kadın okuma-yazma bilmekteydi.

\section{2. Örgün Öğretim}

Şehirde bu dönemde bulunan örgün eğitim kurumları şunlardı:

\subsection{Anaokullar1}

Cumhuriyet’in ilanıyla beraber 1923-1924 eğitim öğretim yllında Kütahya ilinde iki adet anaokulunun toplam 203 öğrencisiyle faaliyet gösterdiği maarif verilerinden anlaşılmaktadır. Okulların açıldıkları mahal verilmemiş olmasına rağmen ileriki yıllara bakılıp bir değerlendirme yapıldığında bu anaokullarının şehir merkezinde ve Uşak ilçesinde faaliyet gösterdiği ifade edilebilir. Maarif salnamelerinde anaokullarının bir ilkokula bağlı olup olmadığı bilgisi verilmemiști. Bu okulların anaokulu olarak ifade edilmiş olması bağımsız statüde hareket ettiklerini göstermekteydi. Ülke genelinde açılan anaokullarının sınıflarına Filiz, Gonca ve Gül isimleri verilerek bir düzen oluşturulduğu tespit edilmişti. Bu çerçevede şehirdeki anaokullarının Filiz Sınıfi 62, Gonca Sınıfi 78 ve Gül Sınıfı da 63 öğrenciye sahipti (1339-1340 İhsâiyat Mecmuası, 1341: 58-59). 1924-1925 eğitim öğretim yılından itibaren Uşak ilçesinde bulunan anaokulunun da öğrenci sayıları verilmekteydi. 1925-1926 eğitim öğretim yllında merkezdeki anaokulunun mevcudu 117 iken Uşak'taki anaokulunun 75’ti. 1926-1927 eğitim öğretim yılı verilerinde anaokulu sayısı üçe çıkmakla beraber yeni açılan anaokulu hakkında bilgi bulunmamaktaydı. Bu döneme kadar verilen istatistiklerde kız erkek ayrımı yapılmamıştı fakat 1926-1927 eğitim öğretim yılında yapılan cinsiyet ayrımında üç okulun tamamının erkek öğrencilerden oluştuğu görülmekteydi. Söz konusu dönemdeki verilere göre öğrenci velilerinin neredeyse yarıya yakını (\%44,54’ü) esnaftı. İkinci sırada memurlar gelmekteydi (\%18,04). 1928-1929 eğitim öğretim yllıyla beraber ilk defa kız öğrencilerin de sayıları verildiği dikkate alındığında bu dönemden itibaren Kütahya'da anaokullarına kız öğrencilerin de gönderilmeye başlandığı söylenebilir. Bu dönemde Filiz Sınıfının öğrenci sayısı 139, Gonca Sınıfının 10 ve Gül Sinifinin da 134 'tü².

Tablo No: 4 1927-1931 Yılları Arasinda Kütahya İlinde Anaokullar1 ${ }^{3}$ (Maarif 1923-1932 İstatistikleri, 1933: 11; 1924-1925 İbsâiyat Mecmuasi, 1927: 32; Devlet Salnamesi 1925-1926, 1926: 799-800)

\begin{tabular}{|c|c|c|c|}
\hline $\begin{array}{c}\text { Ĕ̆itim Öğretim } \\
\text { Y1l1 }\end{array}$ & $\begin{array}{c}\text { Erkek } \\
\text { Öğrenci }\end{array}$ & $\begin{array}{c}\text { K1z } \\
\text { Öğrenci }\end{array}$ & Toplam \\
\hline $1924-1925$ & - & - & 247 \\
\hline $1925-1926$ & - & - & 192 \\
\hline $1926-1927$ & 283 & - & 283 \\
\hline $1927-1928$ & 402 & - & 402 \\
\hline $1928-1929$ & 138 & 124 & 262 \\
\hline $1929-1930$ & 210 & 179 & 389 \\
\hline $1930-1931$ & 189 & 174 & 363 \\
\hline
\end{tabular}

Tablo No: 4'e göre erkek ve kız öğrenci sayıları yıllar içinde inişli çıkışlı bir seyir izlemekteydi. Öğrenci sayısındaki ani düşme ve yükselmenin nedeni belirlenemedi. Maarif Vekâleti

\footnotetext{
2 Her üç anaokulunun toplam mevcudu 283 olmasına karşın maarif verilerinde bu rakam 449 olarak verilmekteydi.

3 1932-1933 yılları arası maarif verilerinde anaokulu mevcutları verilmediğinden ve 1933-1937 y1lları arasıyla ilgili verilere ulaşılamadığından tabloya dâhil edilemedi. 1937-1938 eğitim öğretim y1lı verilerinde anaokulu sayıları toplam içinde değerlendirildiğinden şehir genelinde kaç tane anaokulunun faaliyette olduğu bilgisine ulaşılamadığ için bu veriler de tabloya alınamadi.
} 


\section{KUMAŞ, Nursal (2021). “Atatürk Döneminde Kütahya'da Eğitim İstatistiklerinin Analizi”, Mavi Atlas, 9(1): 275-294}

yaşanan ekonomik sıkıntıdan dolayı ilkokulları rahatlatabilmek için 1925 ve 1930 yıllarında çıkardığ1 genelgelerle anaokullarının bütçesini ilkokullara aktardı. Bu karar üzerine birçok anaokulu kapatılmak zorunda kaldı (Deretarla Gül, 2008: 272). Buna rağmen tablodan da anlaşıldığı kadarıyla Kütahya'daki anaokulları faaliyetlerini sürdürmeyi başardı.

\section{2. İlkokullar}

1923-1924 eğitim öğretim yllında Kütahya ilinde toplam 90 adet ilkokul mevcuttu (13391340 İhsaiyat Mecmuası, 1341: 52). 1924-1925 eğitim öğretim yllında 98 erkek ilkokulunda 6023 ve $13 \mathrm{k} 1 z$ ilkokulunda 1172 olmak üzere toplam 7195 öğrenci bulunmaktaydı. Bu okullardan biri leyliydi ve 50 öğrencisi vardı (1924-1925 İhsâiyat Mecmuası, 1927: 32).

1925-1926 eğitim öğretim yllında Kütahya merkezde üçü erkek ikisi kızlara mahsus olmak üzere toplam 823 öğrencinin devam ettiği beş adet ilkokul, bir adet 50 öğrencili leyli ilkokul vardı. İlkokullardan ikisi numune mektebi olup biri erkeklere ve biri de kızlara aitti. Bu iki okulda toplam 197 öğrenci bulunmaktaydı. Uşak ilçesinde 1925-1926 eğitim öğretim yılında biri erkek ve biri de kızlara ait olmak üzere iki numune okulu mevcuttu (Devlet Salnamesi 1925-1926, 1926: 799-800).

Merkez ilçesine bağlı nahiye ve köy okulları şunlardı: Kütahya Merkez ilçesine bağlı Akçaşehir nahiyesinde üç, Armuteli nahiyesinde üç, Altuntaş nahiyesinde dört ve Gireği nahiyesinde dört olmak üzere toplam 14 erkek ilkokulu mevcut olup bu okullara toplam 567 öğrenci devam etmekteydi. Tavşanlı ilçesinde biri erkek ve biri kızlara ait olmak üzere iki adet ilkokul olup bu okulların toplam öğrenci sayısı 258'di. Tavşanlı ilçesinde toplam 14 ilkokul ve bu okullarda eğitim gören 257 öğrenci vardı (Okulların 9'u merkez nahiyeye, 5’i de Gümüş nahiyesine bağlıydı). Emet ilçesinin merkezinde iki ilkokul bulunmaktaydı ve bu okulların toplam öğrenci sayısı 154'dü (Bu okulların birinde erkek öğrencileri diğerinde kız öğrencileri eğitim görmekteydi). Emet ilçesinin merkez nahiyesine bağlı 7 ve Virancık nahiyesine bağl1 5 adet ilkokul vardı. Bu 12 okulda toplam 517 öğrenci eğitim görmekteydi. Uşak ilçesinde ikisi erkek ve biri kızlara ait olmak üzere üç ilkokul vardı. Bu üç okulda 779 öğrenci eğitim görmekteydi. Gediz ilçesinde birisi numune olmak üzere iki erkek ve iki kız ilkokulu olup toplam öğrenci sayısı $525^{\prime} \mathrm{di}^{4}$. Gediz merkeze bağlı köylerde ve Şaphane nahiyesinde 12 ilkokul mevcut olup öğrenci sayısı 588'di. Simav ilçesinde biri numune olmak üzere iki erkek ve bir kız ilkokulu mevcut olup bu üç okula 297 öğrenci devam etmekteydi. Simav merkezine bağlı köylerde ve Dağardı nahiyesinde 12 okul faaliyette olup bu okullarda 512 öğrenci öğrenim görmekteydi. Uşak merkeze bağlı köylerde beş, Ulubey nahiyesinde altı, Karahallı nahiyesinde sekiz, Sivaslı nahiyesinde dört ve Banaz nahiyesinde dört ilkokul vardı ve bu 27 okulda toplam 1467 ögrenci eğitim görmekteydi (Devlet Salnamesi 1925-1926, 1926: 799-800).

Tablo No: 5 Kütahya'da 1927-1932 Yılları Arasında Faaliyet Gösteren Resmi İlkokullar ve Öğrenci Mevcutlar1 ${ }^{5}$ (Maarif 1923-1932 İstatistikleri, 1933: 22-23, 84-85; Maarif 1932-1933 İstatistikleri, 1934: 4-5)

\begin{tabular}{|c|c|c|c|c|c|c|c|c|c|c|c|}
\hline \multirow{2}{*}{ Dönem } & \multicolumn{3}{|c|}{ Okul Adedi } & \multicolumn{3}{c|}{ Öğrenci Mevcudu } & \multicolumn{2}{c|}{ Öğretmen Mevcudu } & \multicolumn{2}{c|}{$\begin{array}{c}\text { Öğretmenin } \\
\text { Görev Yeri }\end{array}$} \\
\cline { 2 - 14 } & $\begin{array}{c}\text { İl-İlçe } \\
\text { Merkezi }\end{array}$ & Köyler & Top. & $\begin{array}{c}\text { İl-İlçe } \\
\text { Merkezi }\end{array}$ & Köyler & Top. & Erkek & Kadın & Top. & $\begin{array}{c}\text { Ill-İlçe } \\
\text { Merkezi }\end{array}$ & Köyler \\
\hline $1927-1928$ & 21 & 103 & 124 & 3465 & 6521 & 9986 & 202 & 37 & 239 & 112 & 127 \\
\hline $1928-1929$ & 30 & 93 & 123 & 4142 & 5287 & 9429 & 197 & 40 & 237 & 142 & 95 \\
\hline $1929-1930$ & 19 & 114 & 133 & 2984 & 5982 & 8966 & 181 & 35 & 216 & 100 & 116 \\
\hline $1930-1931$ & 20 & 116 & 136 & 3273 & 6618 & 9891 & 198 & 32 & 230 & 110 & 120 \\
\hline
\end{tabular}

\footnotetext{
${ }^{4}$ Usûl-ü cedîd tarzında eğitim öğretim vermek üzere 1872 y1lında İstanbul'da “nümûne iptidẩ” adıyla açılan bu okullar daha sonra Anadolu'da yaygınlaştırıldı (Kodaman, 1991: 67-70).

5 İlgili salnamede toplama yapılırken bazı verilerin sehven girildiği tespit edilerek düzeltildi ve bu şekliyle tabloya yansıtıldı. Sehven yazılanlar; 1927-1928 eğitim öğretim yılı köy öğretmen sayısı 126; 1930-1931 eğitim öğretim y1lı kadın öğretmen mevcudu 31 ve aynı eğitim öğretim yılında il-ilçe merkezlerindeki toplam öğretmen sayıs1 109'du.
} 


\begin{tabular}{|l|l|l|l|l|l|l|l|l|l|l|l|}
\hline $1931-1932$ & 19 & 135 & 154 & 3699 & 7696 & 11.395 & 222 & 41 & 263 & 112 & 151 \\
\hline $1932-1933$ & 19 & 135 & 154 & 3987 & 8285 & 12.272 & 216 & 49 & 265 & 109 & 156 \\
\hline
\end{tabular}

Tablo No: 5’e göre; il genelinde okul sayıs1 \%24,19; öğrenci mevcudu \%22,89 ve öğretmen sayısı da \%10,88 oranlarında artış gösterdi. Öğretmenlerin görev yerleri açısından bir değerlendirme yapıldığında il ve ilçe merkezlerindeki öğretmen sayısı azalma eğilimindeyken köylerde artma eğilimindeydi. Bu dönemde il ve ilçe merkezlerindeki toplam okul sayısı 21'den 19'a düsstü buna karşın köylerde 103 olan rakam 135'e ulaştı. Bu nedenle tablodan da anlaşılacağı üzere öğretmen atamalarında öncelik köylere verilerek yeni açılan okulların öğretmen ihtiyacı giderilmek istenmişti. 1937-1938 eğitim öğretim yllında şehir genelinde 118 resmi ilkokul, 252 öğretmen ve toplam 13.729 öğrenciyle nehari statüde faaliyet göstermekteydi. Bu dönemde verilen sağllk istatistiklerinden okulda görevli bir doktorun olduğu anlaşılmaktadır. Doktorun verdiği bilgilere göre bu dönemde 10 öğrencinin gripten ve 10 öğrencinin de çeşitli hastalıklardan dolayı doktora başvurduğu ve bu öğrencilerin tamamının iyileştiği belirlenmişti (Maarif 1937-1938 Istatistiği, 1939: XXII-XXIII, 306307). 1927 yılı nüfus sayımı sonuçlarında şehrin genelinde toplam 372 adet okul olduğuna dair bir veri yer almaktaydı. Buna karşın söz konusu okulların ne kadarının ilköğretim veya ortaöğretim kademesine ait olduğuna dair bir bilgi bulunmamaktaydı (1927 Umumi Nüfus Sayımı, Fasikül III, 1929: 74). 1932-1933 eğitim öğretim yılında mevcut 154 ilkokulun ilçelere göre dağıllımı sırasıyla şöyleydi: Uşak 40 (merkez: 5, köyler: 35), Merkez 33 (şehir merkezi: 6, köyler: 27), Tavşanlı 25 (merkez: 2, köy: 23), Emet 20 (merkez: 2, köy: 18), Simav 19 (merkez: 2, köy: 17) ve Gediz 17 (merkez: 2, köy: 15). Öğrenci mevutları açısından bir değerlendirme yapıldığında da yine sırasıyla; Uşak 3631 (merkez: 1318, köy: 2313), Kütahya Merkez 2704 (şehir merkezi: 1165; köyler: 1539), Tavşanlı 1639 (merkez: 398, köy: 1241), Simav 1534 (merkez: 410, köy: 1124), Gediz 1390 (merkez: 435, köy: 955) ve Emet 1374'dü (merkez: 261, köy: 1113) (Maarif 1932-1933 Istatistiği, 1934: 58-61). Bu rakamlar okul ve öğrenci sayısında ilk üç sırayı Uşak, Kütahya Merkez ve Tavşanlı ilçelerinin aldığını göstermekteydi. Kütahya il merkezi olmasına karşın Uşak ilçesi eğitim öğretim faaliyetleri açısından daha ön plandaydı.

Öğretmenlerin eğitim durumu 1927-1933 yılları arasında üç ayrı kategori altında değerlendirilebilir: yüksekokul mezunu, öğretmen okulu mezunu ve öğretmenlik diploması olan. Bu grup içinde sayısı en düşük olan yüksekokul mezunlarıydı. Yüksekokul mezunu öğretmenlerin tamamı erkekti ve dönem içindeki sayısı 1-4 arasında değişmekteydi. 1929-1932 yılları arasında il ve ilçe merkezlerinde yüksekokul mezunu öğretmen görev yapmamasına karşın bu dönemde köylerde üç yüksekokul mezunu öğretmen bulunmaktaydı (1930-1931 eğitim öğretim y1l hariç). Öğretmen okulu mezunu olan öğretmenler bu grup içinde en yüksek oranı teşkil etmekteydi ve sayıları il-ilçe merkezlerinde 59-82; köylerde de 6-34 arasında değişmekteydi. 1931-1932 eğitim öğretim yılında köylerde yalnızca iki kadın öğretmen görevliydi. Bu kadın öğretmenlerden biri üç sınıflı öğretmen okulu diğeri de ana öğretmen okulu mezunuydu. Diğer öğretmen okulu mezunlarının tamamı erkekti. Altı yıllık dönem içinde öğretmen okulu mezunu sayısında \%61,1'lik bir artış görülmekteydi.

Üçüncü grupta öğretmenlik diploması olup hukuki olarak öğretmen olma hakkına sahip olanlar yer almaktaydı. 1926 tarihli İlk Mektep Muallim ve Muavinleri Hakkında Kanunun birinci ve ikinci maddesi bu hukuki durumu şöyle ifade etmekteydi:

Birinci Madde: Bu kanunun neşri tarihinde muallim muavini sıfatını ihraz edenler arasında en az beș senelik idadiye muadil tâli veya âli derecede bir mektep tahsili görenler muallim addolunurlar.

İkinci Madde: Birinci maddenin şümulü haricinde kalan muallim muavinlerinden olup yine bu kanunun neşri tarihinde beş sene muvaffakiyetle hizmeti geçmiş olanlar dahi muallim addedilirler.

(Kanunlar Dergisi (2 Haziran 1926). Kanun No: 842, C.4, 1926: 705). 


\section{KUMAŞ, Nursal (2021). “Atatürk Döneminde Kütahya'da Eğitim İstatistiklerinin Analizi”, Mavi Atlas, 9(1): 275-294}

$\mathrm{Bu}$ öğretmenlerin sayısı il ve ilçelerde 6-27 ve köylerde 6-85 arasında değişiklik göstermekteydi. Kütahya Maarif Müdürlüğünün bu dönemde nitelikli öğretmenleri kırsal alanda değerlendirme eğiliminde olduğu anlaşılmaktadır.

Asil ve daimi statüde çalışan öğretmenlerin yanında vekil öğretmenler ve geçici-daimi yardımcı öğretmenler de bulunmaktaydı. 1 Kasım 1928 tarihinde Harf İnkılabı yapıldığı dikkate alındığında yeni harfleri öğrencilere tanıtmak ve okuma-yazmayı yaygınlaştırmak amacıyla vekil öğretmenlerden büyük oranda yararlanıldığı tespit edildi. 1928-1929 eğitim öğretim yllında il-ilçe merkezlerinde 69; köylerde de 88 olmak üzere toplamda 157 vekil öğretmen görevliyken bu say1 1929-1930 eğitim öğretim yllında oldukça azalarak 13'e düştü. Bu durum söz konusu öğretmenlerin millet mekteplerinde olduğu gibi sadece okuma-yazma öğretmek ve temel bilgileri öğrencilere aktarmak amacıyla geçici olarak alındığı sonucunu ortaya çıkarmaktaydı. Bu konuda herhangi bir veri bulunmamasına karşın, Maarif Vekâletinin bu dönemde öğretmenlik kursları açarak vekil öğretmenlere diploma verdiği ve böylelikle vekil öğretmenlerden boşalan görevlerin öğretmenlik diploması alanlar tarafından doldurulmaya çalışıldığı ifade edilebilir. Bu dönemde uygulanan geçici ve daimi muavin öğretmen uygulamasının dönem içinde azaltıldığını ve il-ilçelerde 43 olan sayının 1'e ve köylerde 105'ten 23'e indirildiği tespit edildi.

Kütahya Maarif Müdürlügünün 1927-1933 yılları arasında personel maaşlarıyla beraber yılllk masraf1 199.992-319.328 lira arasında değişkenlik göstermekteydi (Maarif 1923-1932 İstatistikleri, 1933: 98; Maarif 1932-1933 İstatistiği, 1934: 162-163). Masraf miktarının artışında öğretmen sayısında yaşanan artış da etkiliydi.

1932-1933 eğitim öğretim yllında Türkiye genelinde resmi ilkokullarda öğretmen başına düşen öğrenci sayıs1 39 iken bu sayı Kütahya il genelinde 46 olup ortalamanın üstündeydi. Maarif Vekâleti resmi ilkokullar için her yıl belli bir miktarda bütçe ayırmaktaydı. Resmi ilkokullar söz konusu bütçe aracıllğıyla birtakım ihtiyaçlarını karşılamaktaydı. Maarif salnamelerinde il bazında yapılan harcama miktarı ildeki toplam öğrenci sayısına bölünerek bir ilkokul öğrencisine düşen harcama miktarı tespit edilmekteydi. 1932 yılı verilerine göre elde edilen rakamlar 11-66 lira arasında değişkenlik gösterirken bu rakam Kütahya ili için 17 liraydı. (Maarif 1932-1933 İstatistiği, 1934: XIXII). Bu dönemde ilkokullardan mezun sayısı il ve ilçe merkezlerinde 265 ve köylerde 40 olmak üzere toplam 305'ti (Maarif 1932-1933 İstatistiği, 1934: 14-15).

Kütahya'da Osmanlı Devleti'nin son dönemlerinde veya Cumhuriyet'in ilanının hemen ardından ilkokul olarak açıllp günümüzde de eğitim öğretim faaliyetlerini sürdüren bazı okullar şunlardı: Fevzi Hürriyet Mektebi İbtidaiyye, Devletşah Kız İlk Mektebi, Lala Hüseyin Paşa ve Gazi Kemal (Kütabya İli Cumburiyet Öncesi ve Sonrası Eğitim, 1998: 98-112).

\subsection{Ortaokullar}

Maarif verilerine göre; 1923-1924 eğitim öğretim yllında Kütahya merkezde toplam 181 öğrencinin (163 erkek ve 18 kız) eğitim gördüğü bir ortaokul bulunmaktaydı (1339-1340 İhsâiyat Mecmuasi, 1341: 66). Bu okulun 1924-1925 eğitim öğretim y1lında 20 öğretmen ve 92 öğrencisi vard1 (1924-1925 İhsâiyat Mecmuası, 1927: 38). 1925-1932 y1lları arasında biri Kütahya merkezde ve diğeri de Uşak ilçesinde olmak üzere nehari eğitim veren iki adet ortaokulun olduğu tespit edildi. 19321933 yıllarına ait maarif verilerinde bu iki okula ek olarak merkezde 85 (erkek: 70, kız: 15) öğrencili resmi ikmal mektebi yer almaktaydı. Aynı dönemde merkezde ve Uşak ilçesinde yer alan ortaokullardaki toplam öğrenci sayısı 389 erkek ve 57 kız olmak üzere 446'ydı. Bu dönemde 39'u erkek ve 10'u kız olmak üzere toplam 49 öğrenci mezun olmuştu (Maarif 1932-1933 İstatistiği, 1934: 174). 1930-1931 eğitim öğretim yllında 36 öğrenci (4’ü ücretli, 32’si ücretsiz) ve 1931-1932 eğitim öğretim y1lında 51 (4’ü ücretli, 47’si ücretsiz) öğrenci pansiyonda kalmaktaydı. 
Tablo No: 6 Kütahya'da 1927-1932 Y1lları Arasında Faaliyet Gösteren Resmi Ortaokulların Öğrenci Mevcutlar16 (Maarif 1923-1932 Istatistikleri, 1933: 42-45; Devlet Salnamesi 1925-1926, 1926: 799-800).

\begin{tabular}{|l|c|c|c|c|c|c|}
\hline \multirow{2}{*}{ Dönem } & \multicolumn{3}{|c|}{ Kütahya Merkez Ortaokulu } & \multicolumn{3}{c|}{ Uşak Ortaokulu } \\
\cline { 2 - 7 } & \multicolumn{3}{|c|}{ Öğrenci Mevcutlar1 } & \multicolumn{3}{c|}{ Öğrenci Mevcutlar1 } \\
\cline { 2 - 7 } & Erkek & Krz & Toplam & Erkek & K1z & Toplam \\
\hline $1925-1926$ & $?$ & $?$ & 197 & $?$ & $?$ & 248 \\
\hline $1927-1928$ & 112 & - & 112 & 137 & - & 137 \\
\hline $1928-1929$ & 113 & 24 & 137 & 131 & 12 & 143 \\
\hline $1929-1930$ & 143 & 25 & 168 & 94 & 5 & 99 \\
\hline $1930-1931$ & 170 & 23 & 193 & 106 & 7 & 113 \\
\hline $1931-1932$ & 204 & 19 & 223 & 127 & 18 & 145 \\
\hline
\end{tabular}

Tablo No: 6 ve Grafik No: 3'deki verilere göre; Kütahya merkez ortaokulu öğrenci sayısı 1927-1928 eğitim öğretim y1lında sebebi tespit edilemeyen bir nedenden dolayı keskin bir düşüş yaşadı fakat 1928-1932 yılları arasında sürekli artış eğilimi gösterdi. Uşak ortaokulu öğrenci mevcutları dönem içinde inişli çıkışlı bir seyir izlemekteydi ${ }^{7}$. 1932-1933 eğitim öğretim y1lında il genelinde bulunan 3 ortaokulda 24'ü erkek ve 6's bayan olmak üzere toplam 30 ögrretmen görev yapmaktaydı (Maarif 1932-1933 Istatistiği, 1934: 173). Öğretmenlerden 4'ü resmi ikmal mektebinde görevliydi. Ortaokul öğretmenlerinden birinin Avrupa'da, dördünün de Türkiye'de yükseköğrenim yaptığ1 ve altısının da Darülfünun mezunu olduğu tespit edildi (Maarif 1932-1933 İstatistiği, 1934: 193).

Grafik No: 3 Kütahya İlindeki Ortaokullarda Öğrenim Gören Öğrenci Sayıları (Tablo No: 6’daki verilere göre hazırlandi)

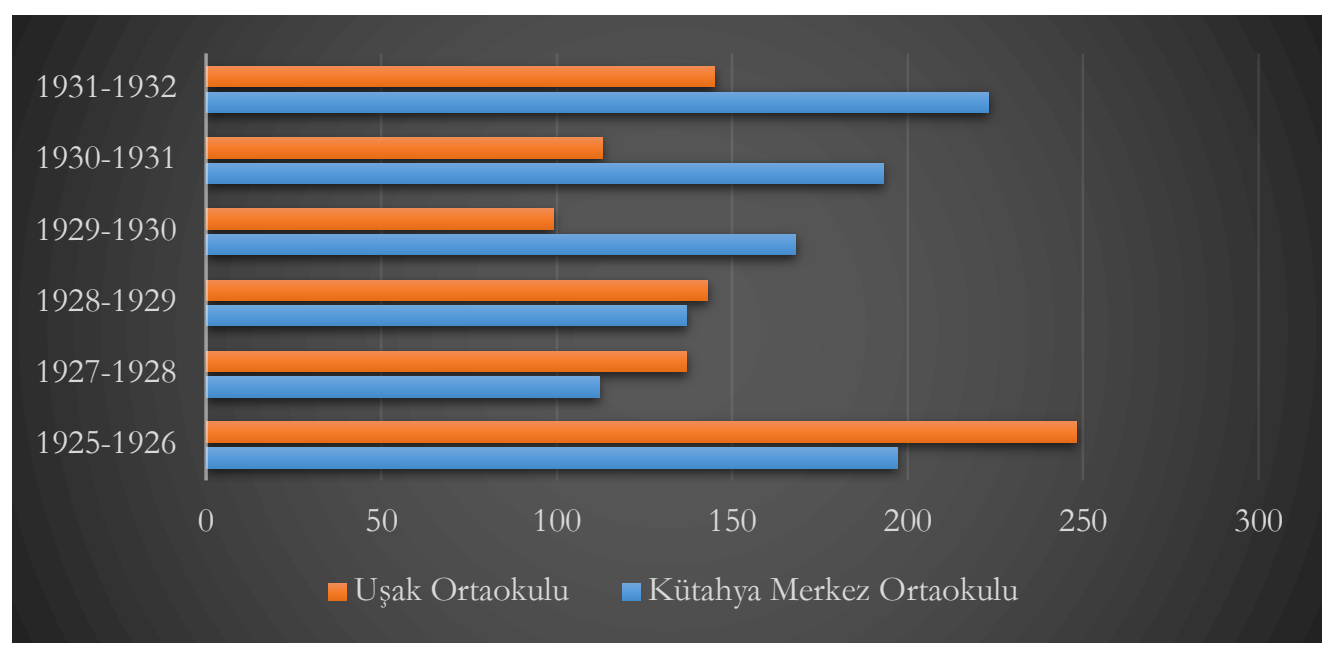

1937-1938 eğitim öğretim yılında il genelindeki mevcut iki ortaokulda 32 öğretmen ve 602 öğrenci öğrenim görmekteydi.

1932 y1l itibarıyla şehirdeki iki ortaokul için ayrılan bütçe 17.309 liraydı. Bu rakam diğer şehirlerdeki karma ortaokul bütçeleriyle karşılaştırıldığında ülke sıralamasında yedinci sırada gelmekteydi. Maarif verilerinde 1932-1933 eğitim öğretim yilında sadece iki adet ikmal ortaokulunun ismi ve bütçe miktarı verilmekteydi. Bu okullardan biri Cebelibereket ilindeydi ve

\footnotetext{
${ }^{6}$ İlgili salnamede 1929-1930 eğitim öğretim y1lı toplam öğrenci mevcudunun sehven 256 olarak girildiği tespit edildi.

${ }^{7}$ Her iki ortaokulun 1925-1926 eğitim öğretim yilıyla ilgili öğrenci mevcutları devlet salnamesinden diğer yıllara ait veriler maarif salnamesinden alınmışır.
} 


\section{KUMAŞ, Nursal (2021). “Atatürk Döneminde Kütahya'da Eğitim İstatistiklerinin Analizi”, Mavi Atlas, 9(1): 275-294}

bütçesi 4973 liraydı. Diğeri Kütahya’nın Simav ilçesindeydi ve bütçesi 5805 liraydı (Maarif 19321933 Istatistiği, 1934: 197).

\subsection{Kütahya Lisesi}

Kütahya merkezde 1890 yllında liva idadisi olarak açlan bu okul, 1913-1914 eğitim öğretim yllında ziraat idadisi ve 1917-1918 eğitim öğretim yllında da Sultani Mektebi olarak faaliyet gösterdi. Cumhuriyet Dönemi’nde ilkokul kısmı kaldırıldı ve üç yıl eğitim vermeye başladı. 1933-1934 eğitim öğretim yılında liseye dönüştürüldü fakat aynı yıl yang1n çıktığı için faaliyetlerini sürdüremedi. Öğrenciler şehir merkezindeki Özel İdare Pansiyonunda ve Gazi Kemal İlkokulunda bir süre eğitimlerine devam etmek zorunda kaldı. Okul gerekli tamiratın yapılmasından sonra 1 Mayıs 1938 tarihinde eğitim öğretim faaliyetlerine yeniden başladı (Kaçmaz, 2010: 8-10; Çetintaş, 2017: 9). 1937-1938 eğitim öğretim yllında karma eğitim veren lisenin orta kısmında 342 ve lise kısmında 150 olmak üzere toplam 492 öğrencisi vardı (Maarif 1937-1938 Istatistiği, 1939: 206). Bu dönemde okul doktorunun verdiği bilgiye göre 37 öğrenciye grip, bir öğrenciye karahumma, bir öğrenciye y1lanc1k, iki öğrenciye verem hastalığı ve 27 öğrenciye de çeşitli hastalıklarla ilgili teşhisler konuldu. Bu hastalardan sadece iki tanesi tedavisine devam etmekteydi ve diğerleri tamamen iyileşmişti (Maarif 1937-1938 Istatistiüz, 1939: 304-305).

\subsection{Meslek Okulları}

Kütahya merkezde ziraat ve sanayi alanında uygulanan teknikleri geliştirerek kalitesi ve hasılatı yüksek ürün elde etmek amacıyla 29 Ekim 1924 tarihinde eğitim öğretim faaliyetlerine başlayan bir sanayi ve zirai yurdu bulunmaktaydı. İlkokul düzeyinde ve leyli (yatılı) olarak üç yıl eğitim vermekteydi. Kütahya Sanayi Zirai Yurdunun arıcıllk, tavukçuluk, sütçülük ve konservecilik bölümleri bulunmaktaydı. Yurtta ayrıca inşa edilen demirhanede Avrupa'da kullanılan pulluklar imal edilmekteydi (Kütabya, S. 1, 1 Aralık 1925: 7). Bu okul 1925-1926 eğitim öğretim yllında idare-i hususiye (özel idare) tarafından yönetilmekteydi ve öğrenci sayısı da 42'ydi. Bir sonraki eğitim öğretim yılında bu sayı 50'ye çıktı. Uşak ilçesinde de leyli olarak eğitim veren 44 öğrencinin devam ettiği bir yetimler yurdu vard1 (Devlet Salnamesi 1925-1926, 1926: 800; Devlet Salnamesi 1926-1927, 1927: 1076).

Yurdun kendine ait bir matbaası mevcuttu. Bu matbaada Sanayi ve Ziraiye Yurdu tarafindan Kütahya gazetesi ismiyle bir gazete basılmaktaydı. Gazete 15 günde bir yayımlanmakta olup zirai, ilmi, edebi, fenni konulara değinmekteydi. Gazetenin sahibi ve mesul müdürü aynı zamanda yurt müdürü olan Mehmet Nuri Bey'di (Devlet Salnamesi 1926-1927, 1927: 1076).

Kütahya Merkez ilçede 1923-1924 eğitim öğretim yllında üç ylllı eğitim veren imam hatip okulu vardı ve öğrenci sayısı 87’ydi (1339-1340 İhsâiyat Mecmuası, 1341: 47). Uşak ilçesindeki imam hatip okulunun hangi tarihte açıldığı tespit edilememiş olmasına karşın 1924-1925 eğitim öğretim yllında maarif salnamesinde ismi geçmekteydi. Bu dönemde her iki imam hatip okulunda 77 öğrenci eğitim görmekteydi (1924-1925 İbsâiyat Mecmuası, 1927: 32-33).

\section{Yaygın Ĕgitim}

Okul çağ1 dışında kalan nüfusun eğitilmesi amacıyla Cumhuriyet Dönemi'nde ülke genelinde birtakım yaygın eğitim kurumları açıldı. Bu kurumların başında millet mektepleri, halkevleri ve Maarif Vekâletinin açtı̆̆ çeşitli kurslar gelmekteydi. Osmanlı Devleti'nin son dönemlerinde açılan Türk Ocağı ve çeşitli dönemlerde açılan kütüphaneler de yaygın eğitime yardımcı kurumlardı. Bu bağlamda Kütahya ilinde adı geçen yaygın eğitim kurumları yöre halkına hizmet vermekteydi. 


\section{KUMAŞ, Nursal (2021). “Atatürk Döneminde Kütahya'da Eğitim İstatistiklerinin Analizi”, Mavi} Atlas, 9(1): 275-294

\subsection{Millet Mektepleri}

Cumhuriyet yönetimi tarafından 1 Kasım 1928 tarihinde kabul edilen Latin Harflerini Türk halkına tanıtmak, okuma-yazmayı yaygınlaştırmak ve temel konularda eğitim vermek amacıyla 1 Ocak 1929 tarihinde millet mektepleri açıldı (BCA, F.490.1.0.0/1.2.13/1). Bu mekteplere yönelik bir talimatname hazırland. Talimatnamenin 15. maddesinde her ilde idari taksimata göre merkez ilçe, ilçe, nahiye, köy veya mahallelerde millet mektepleri açılması öngörülmekteydi (Millet Mektepleri Talimatnamesi, 1929: 7$)^{8}$. Bu bağlamda Kütahya ilinde de millet mektepleri kuruldu. Kütahya gazetesinde yer alan bir haberde Kütahya Vali Konağında düzenlenen bir törenle Latin Harfleriyle okuma-yazma faaliyetlerinin başladığını ve dönemin Kütahya Valisi Fevzi Bey'in Latin Harflerinin kabul edilmesinden kısa bir süre sonra Uşak, Gediz ve Simav ilçelerine giderek bu ilçelere bağlı nahiye ve köylerde kurslar açılması yönünde gerekli teşkilatlanmayı sağlamaya çalıştığ1 anlaşılmaktaydı. Ayrıca Kütahya gazetesinde Latin Harfleri tanıtılmakta ve bu harflerden üretilen çeşitli kelimelere yer verilmekteydi (Kütabya, 69, 15 Ekim 1928: 9-13).

Tablo No: 7 1928-1935 Eğitim Öğretim Yllında Kütahya'da Millet Mekteplerinin Öğrenci ve Öğretmen Mevcutlar1 (Maarif 1928-1935 Millet Mektepleri, 1935: 46; 1928-1934, 1934: 32; 1928-1933, 1934 : 28)

\begin{tabular}{|c|c|c|c|c|c|c|c|c|c|c|c|c|c|c|c|c|}
\hline & \multirow{3}{*}{ Y11 } & \multicolumn{6}{|c|}{ Dershane Sayıs1 } & \multirow{2}{*}{\multicolumn{3}{|c|}{$\begin{array}{l}\text { Öğretmen } \\
\text { Mevcudu }\end{array}$}} & \multicolumn{6}{|c|}{ Devam Eden Ö̆ğrenci Sayıs1 } \\
\hline & & \multicolumn{3}{|c|}{ A Sinifi } & \multicolumn{3}{|c|}{ B Sinifi } & & & & \multicolumn{3}{|c|}{ A Sinıfi } & \multicolumn{3}{|c|}{ B Sinifi } \\
\hline & & $\mathbf{E}$ & $\mathbf{K}$ & $\mathbf{T}$ & $\mathbf{E}$ & $\mathbf{K}$ & $\mathbf{T}$ & $\mathbf{E}$ & $\mathbf{K}$ & $\mathbf{T}$ & $\mathbf{E}$ & $\mathbf{K}$ & $\mathbf{T}$ & $\mathbf{E}$ & $\mathbf{K}$ & $\mathbf{T}$ \\
\hline \multirow{7}{*}{ 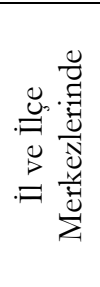 } & $1928-1929$ & 42 & 19 & 61 & 5 & 2 & 7 & 47 & 21 & 68 & 2250 & 961 & 3211 & 219 & 85 & 304 \\
\hline & $1929-1930$ & 53 & 37 & 90 & 14 & 8 & 22 & 73 & 38 & 111 & 2412 & 1855 & 4267 & 552 & 299 & 851 \\
\hline & $1930-1931$ & 44 & 26 & 70 & 10 & 6 & 16 & 54 & 32 & 86 & 2589 & 1504 & 4093 & 262 & 242 & 504 \\
\hline & $1931-1932$ & 18 & 10 & 28 & 8 & 2 & 10 & 26 & 12 & 38 & 625 & 266 & 891 & 266 & 91 & 357 \\
\hline & $1932-1933$ & 4 & 4 & 8 & 1 & 1 & 2 & 5 & 5 & 10 & 159 & 129 & 288 & 60 & 61 & 121 \\
\hline & 1933-1934 & - & - & - & - & - & - & - & - & - & - & - & - & - & - & - \\
\hline & 1934-1935 & 8 & 7 & 15 & 3 & - & 3 & 11 & 7 & 18 & 234 & 127 & 361 & 144 & - & 144 \\
\hline \multirow{7}{*}{ 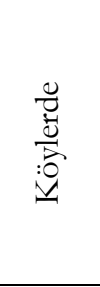 } & 1928-1929 & 81 & 5 & 86 & - & - & - & 81 & 5 & 86 & 2066 & 673 & 2739 & - & - & - \\
\hline & 1929-1930 & 102 & 6 & 108 & - & - & - & 102 & 6 & 108 & 2782 & 1889 & 4671 & - & - & - \\
\hline & 1930-1931 & 96 & 2 & 98 & - & - & - & 96 & 2 & 98 & 2789 & 1534 & 4323 & - & - & - \\
\hline & $1931-1932$ & 44 & - & 44 & - & - & - & 44 & - & 44 & 1815 & 390 & 2205 & - & - & - \\
\hline & 1932-1933 & - & - & - & - & - & - & - & - & - & - & - & - & - & - & - \\
\hline & 1933-1934 & - & - & - & - & - & - & - & - & - & - & - & - & - & - & - \\
\hline & 1934-1935 & 77 & 26 & $105^{9}$ & 33 & 4 & 37 & 89 & 1 & 90 & 2059 & 591 & 2650 & 756 & 57 & 813 \\
\hline \multirow{7}{*}{ 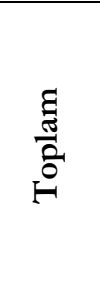 } & $1928-1929$ & 123 & 24 & 147 & 5 & 2 & 7 & 128 & 26 & 154 & 4316 & 1634 & 5950 & 219 & 85 & 304 \\
\hline & 1929-1930 & 155 & 43 & 198 & 14 & 8 & 22 & 175 & 44 & 219 & 5194 & 3744 & 8938 & 552 & 299 & 851 \\
\hline & 1930-1931 & 140 & 28 & 168 & 10 & 6 & 16 & 150 & 34 & 184 & 5378 & 3038 & 8416 & 262 & 242 & 504 \\
\hline & 1931-1932 & 62 & 10 & 72 & 8 & 2 & 10 & 70 & 12 & 82 & 2440 & 656 & 3096 & 266 & 91 & 357 \\
\hline & 1932-1933 & 4 & 4 & 8 & 1 & 1 & 2 & 5 & 5 & 10 & 159 & 129 & 288 & 60 & 61 & 121 \\
\hline & 1933-1934 & - & - & - & - & - & - & - & - & - & - & - & - & - & - & - \\
\hline & 1934-1935 & 85 & 33 & $120^{10}$ & 36 & 4 & 40 & 100 & 8 & 108 & 2293 & 718 & 3011 & 900 & 5711 & 957 \\
\hline
\end{tabular}

Tablo No: 7’ye göre; Latin Harflerinin kabul edildiği 1928 tarihinden 1930 y1lına kadar millet mekteplerinin sayısında ve öğrenci mevcutlarında artış yaşanırken bu dönemden sonra açlan dershane sayısı ve devam eden öğrenci sayısı azalma eğilimine girdi. İl ve ilçe merkezlerinde 19331934 ve köylerde de 1932-1934 yılları arasında dershane açılmadı. Köylerde 1928-1931 yılları arasında açılan dershane sayısıyla kadın köy öğretmeni sayısının yıllara göre aynı olması köylü

\footnotetext{
${ }^{8}$ Millet Mektepleri Talimatnamesi için ayrıca bakınız: BCA, F.490.1.0.0/1.3.12/6-54, 28 Ekim 1929.

${ }_{9}$ İki öğrencinin cinsiyeti belli değildi.

${ }^{10}$ Cinsiyeti belli olmayan iki kadın öğrenci toplama dâhil edildi.

11 İlgili kaynakta bu rakam sehven 97 olarak gösterilmekteydi.
} 
kadınların sadece kadın öğretmenler tarafından ders aldıklarını göstermekteydi. Kadın köy öğretmeni sayısının yetersiz olması köylerde açılan dershanelerin erkekler için açılan dershanelere oranla oldukça az sayıda kalmasına neden oldu. Köy kadınlarının erkek öğretmene karşı tutumları değişmiş olmalı ki 1934-1935 eğitim öğretim yılında yalnızca bir kadın köy öğretmeni görev yapmasına karşın kadınlara yönelik 30 dershane açıldı.

Kütahya'da millet mektepleri için ayrılan bütçenin 1928-1929 eğitim öğretim y1lında 795 lira; 1929-1930: 19.153 lira; 1930-1931: 13.383 lira ve 1931-1932: 5923 lira olduğu tespit edildi (Maarif 1928-1935 Millet Mektepleri, 1935: 77).

Millet mektepleri talimatnamesine bağlı olarak halka okuma alıskanlığı kazandırmak amaciyla halk okuma odaları kuruldu. Bu odaların faaliyetlerini düzenleyen ayrı bir talimatname hazırland1 (Halk Okuma Odalar Rehberi, 1929). 1933-1934 eğitim öğretim yllı itibarnyla ülke genelinde toplam 778 adet okuma odası olmasına karşın Kütahya genelinde okuma odasının bulunmuyor olması dikkat çekici görünmekteydi (Maarif 1933-1934 Halk Okuma Odalar ve Umumî Kütüphaneler Istatistiği, 1935: 3).

\subsection{Türk Ocă̆1}

Türk Ocağı, Türk milliyetçiliği anlayışını toplumsal tabana yerleştirmek amacıyla 22 Mart 1912 tarihinde resmen kuruldu. Kurtuluş mücadelesine destek veren bu kurum Cumhuriyet Dönemi'nde özellikle Atatürk ilkelerinden halkçılık ve milliyetçilik anlayışını halka anlatmaya çalıştı. 10 Nisan 1931 tarihinde son kongresini gerçekleştiren ocak, tarihi görevini tamamladığ1 gerekçesiyle kapatıldı ve bütün hakları Cumhuriyet Halk Partisine devredildi (Arıkan, Deniz, 2004: 403-412). Ülkede pek çok şubesi olan ocağın, Kütahya ve ilçelerinde de şubeleri bulunmaktaydı. Arşiv belgelerinden anlaşıldığı kadarıla başta Kütahya şehir merkezinde olmak üzere bu ile bağlı Uşak, Gediz, Simav, Emet ve Tavşanlı ilçeleriyle Ulubey nahiyesinde de Türk Ocağının şubeleri mevcuttu (BCA, F.490.1.0.0/69.260.1/136). Türk Ocağının Kütahya Merkez ilçede ne zaman kurulduğu ve ne tür faaliyetler gösterdiği tespit edilemedi fakat 1925-1926 eğitim öğretim y1lında faaliyette olduğu söylenebilir (Devlet Salnamesi 1925-1926, 1926: 798).

Türk Ocağının 1924 yılının Nisan ayında gerçekleştirdiği kongre neticesinde Türk Ocağı Yasası kabul edildi. Bu yasada şöyle denilmekteydi: Bütün Türkler arasinda milli şuurun takviyesine, Türk harsınm meydana çıkarlmasina, medeni, sıbhi tekâmüle ve milli iktisadın inkişafina çalıs̆maktır (Karaduman, 2007: 509). Bu çerçevede şehirdeki Türk Ocağının kapatıldığı 1931 yılına kadar Kütahya'nın eğitim hayatına destek verdiği ifade edilebilir.

Türk Ocağının kapatılmasından sonra Kütahya ve ilçelerindeki bu şubelerin de tasfiye süreci başladı. Kütahya il merkezinde bulunan Türk Ocağından kalan üç katlı bahçeli bina halkevine dönüştürüldü. Ocağa ait han, lokanta ve arsalar da Tayyare Cemiyetinin Kütahya şubesine satıldı (BCA, F.490.1.0.0/69.260.1/48/83). Nur Mektebi adıyla anılan Uşak Türk Ocağının binası okul yapılmak amacıyla Kütahya Valiliğinin müracaatı üzerine İl Özel İdaresi (Mahalli Hususi İdare) tarafından 1934 yılında 2000 liraya satın alındı. Kütahya valisi bu binanın aslında okul yapılması için elverişli olmadığını ama okulu yeniden inşa etme maliyetinin yüksek oluşu nedeniyle Nur Mektebini satın almak zorunda kaldıklarını ifade etmekteydi (BCA, F.490.1.0.0/69.260.1/26/36).

\subsection{Kütahya ve Simav Halkevlerinin Eğitim Faaliyetleri}

Cumhuriyet Dönemi'nin başlarında gerçekleştirilen inkılap hareketlerini Türk halkına tanıtmak ve benimsetmek amacıyla 19 Şubat 1932 tarihinde halkevleri açlldı. Kültür kurumları olarak adlandırılan halkevleri dokuz şubeyle yapılandırıldı: Dil-Tarih-Edebiyat, Gürel Sanatlar, Temsil, Spor, İ̧timâ̂ Yardım, Halk Dershaneleri ve Kurslar, Kütü̈hane ve Neşriyat, Köycüler, Müze ve Sergi (CHF Halkevleri Talimatnamesi, 1932: 6). CHP yönetiminin bu şubelerden beklentisi halkın tiyatro, sinema, konser, konferans, müze, sergi gibi faaliyetler aracllğıyla kültürel düzeylerini yükseltmek, 
bünyesinde kütüphaneler kurarak halka kitap okuma sevgisi aşılamak, beden sağlığının korunması amacına yönelik olarak bireyleri sportif faaliyetlere özendirmek ve yardıma muhtaç halka çeşitli imkânlar sunarak sosyal dayanışmayı artırmaktı.

Parti yönetimi halkevleri aracıllğıyla özellikle yetişkinlerin eğitim düzeylerini de yükseltmeyi hedeflemekteydi. Bu amaçla halkevlerinden dershaneye dönüşmeden halka sanat, edebiyat ve spor alanlarında birtakım dersler verilmesi istenmekteydi. Kültürel faaliyetler ve sportif etkinlikler eğitimin bir parçasıydı fakat parti yönetimi için öğretim boyutu son derece önemliydi. Bu amaç doğrultusunda halkevlerinin halk dershaneleri ve kurslar, güzel sanatlar ve temsil şubeleri aracillğıyla birçok alanda kurslar düzenlediği anlaşılmaktaydı. Bu kurslar alanında uzman öğretmenler tarafindan ücretsiz olarak verilmekteydi.

Kütahya Halkevi 24 Haziran 1932 tarihinde (Değerli, Yapıcı, 2018: 4) ve Simav Halkevi de 22 Şubat 1935 tarihinde açıldı. Kütahya Halkevi Halk Dershaneleri ve Kursları Şubesi 1935 yılının ilk altı ayı içinde köylerde dört ve şehir merkezinde 17 dershane açtı. Bu dershanelerde Türkçe, İngilizce ve müzik kursları düzenlendi. Dört ay süren kurslara 258 kadın ve 582 erkek olmak üzere toplam 840 kursiyer katıldı. Yılın ikinci altı ayı içinde şehir merkezinde iki ilave dershane açldı ve 16 kadın 45 erkek olmak üzere toplam 61 kursiyer kaydedildi (BCA, F.490.1.0.0/989.829.1/43).

Tablo No: 8 1934-1935 Eğitim Öğretim Y1lında Kütahya'da Açllan Halk Dershaneleri ve Kursiyer Saylant (BCA, F.490.1.0.0/ 989.829.1/52, 1 Şubat 1938)

\begin{tabular}{|c|c|c|c|c|}
\hline Dershanenin Açıldı̆̆1 Yer & $\begin{array}{c}\text { Dershane } \\
\text { Say1s1 }\end{array}$ & $\begin{array}{c}\text { Kadın } \\
\text { Kursiyer }\end{array}$ & $\begin{array}{c}\text { Erkek } \\
\text { Kursiyer }\end{array}$ & Toplam \\
\hline Şehir Merkezi (kadınlar için) & 1 & 20 & - & 20 \\
\hline Şehir Merkezi (erkekler için) & 3 & 20 & 55 & 75 \\
\hline Merkez Alayunt Köyü & 1 & - & 30 & 30 \\
\hline Merkez Saka Köyü & 1 & - & 50 & 50 \\
\hline Altuntaș Beşkarıș Köyü & 2 & 40 & 50 & 90 \\
\hline Altuntaş Çal Köyü & 1 & - & 90 & 90 \\
\hline Altuntaş Kürt Köyü & 1 & - & 35 & 35 \\
\hline Altuntaş Zemme Köyü & 2 & 25 & 30 & 55 \\
\hline Armuteli Doğlişa Köyü & 2 & 53 & 62 & 115 \\
\hline Armuteli Sofcu Köyü & 1 & - & 50 & 50 \\
\hline Gümüş Köprüören Köyü & 2 & 40 & 50 & 90 \\
\hline Gümüş Kükürt Köyü & 2 & 40 & 40 & 80 \\
\hline Gümüş Seydi Ömer Köyü & 2 & 20 & 40 & 60 \\
\hline Toplam & 21 & 258 & 588 & 846 \\
\hline
\end{tabular}

Tablo No: 8'e göre; beş köyde hiç kadın kursiyer bulunmamaktaydı. Kadın kursiyer sayısı tüm kursiyerler içinde \%30,50 oranındaydı. Millet mekteplerinde olduğu gibi halk dershanelerinde de kadın kursiyer sayısı erkeklere oranla oldukça düşüktü. Bu nedenle Atatürk döneminde özellikle Kütahya ilinin köylerinde ikâmet eden kadınların yeterli düzeyde okuma-yazma faaliyetlerinden yararlanamadığı anlaşılmaktaydı.

1 Kasım 1937 tarihinde halkevi bünyesinde yetişkinlere yönelik olarak okuma-yazma kursu açıldı. Bu kurs için halkevi bünyesinde iki adet sınıf oluşturuldu. Kursa 66 kişi kayıt oldu ve 58 kişi düzenli olarak devam etti. Kursiyerlerin kalem ve kitap gereksinimleri şube bütçesinden karşılandı (BCA, F.490.1.0.0/989.829.1/1).

Halkevinin Kitapsaray ve Yayın şubesi bünyesinde 1935 yllı verilerine göre 1550 kitap ve 1342 dergi vard1. Okuyucu sayısı da 3962'ydi. Şube üyeleri şehirde yayımlanan Kütahya gazetesinde halkı bilgilendirici çeşitli çalışmaları kaleme alarak yöre halkının kültürel düzeyini artırmayı hedefledi. Bu bağlamda ayrıca belirli gün ve haftalar kapsamında alanında uzman kişilere konferanslar verdirildi. Simav Halkevi Kitapsaray ve Yayım Şubesi bünyesinde 1050 kitap vardı. 
1935 yllı içinde 2496 kişi okuyucu olarak bu kitaplardan istifade etti (BCA, F.490.1.0.0/989.829.1/2/26/29/53).

Temsil şubesi halkevi salonunda temsiller sergileyerek yöre halkını tiyatroyla tanıştırdı. Ülke genelinde faaliyet gösteren temsil şubelerinin bayan üyeleri Batı kültürüne ait kültürel unsurları henüz özümseyemeyen halkın karşısında rol almak istemiyordu. Arşiv belgelerinden anlaşıldığ1 kadarıyla Kütahya Halkevi bu sorunu çözdü ve bayan üyelerin temsillerde istekli olarak görev almasını sağladı. Aynı başarıyı Simav Halkevi gösteremedi fakat temsil şubesinin 1935 yllı içinde sergilediği dört temsil yöre halkından büyük bir ilgi gördü (BCA, F.490.1.0.0/989.829.1/2$3 / 25 / 27)$.

Halkevinin güzel sanatlar şubesi bando ve salon orkestrası kurdu. Salon orkestrası aracilığıyla hafta sonları yerel halk konserlerle tanışma firsatı buldu. Simav Halkevi Güzel Sanatlar Şubesinin kurmuş olduğu bando ve caz kurulu ilçenin sosyal hayatına bir renk getirdi. Milli günlerin değişmez bir unsuru haline geldi. Halkevi temin ettiği radyo aracıllğıyla da yöre halkına sanat kültürü kazandırmaya çalıştı. Dil, tarih ve edebiyat kolu da yörenin dil ve tarihiyle ilgili çalışmalarda bulundu (BCA, F.490.1.0.0/989.829.1/4/24).

Kütahya Halkevi Spor Şubesi güreş dersleri, Simav Halkevi Spor Şubesi Avc1lık Kolu da üyelerine atıcılık dersleri vermekteydi. Şube bünyesinde atletizm, binicilik ve futbol alanında faaliyetler sürdürülmekteydi. Şube üyeleri bir taraftan sportif faaliyetlerde bulunurken diğer taraftan da şubeye kayıtlı öğretmenler tarafından çeşitli konferanslar aracilı̆̆ıla bilgilendirilip eğitim seviyeleri artırılmaya çalışılmaktaydı. Kütahya Halkevi Köycülük Şubesi üyeleri 19 köy gezisine çıkarak köylülere 320 adet dergi dağıttı. Köylülerle inkılapların önemi üzerine konuşmalar yapıldı ve eğitici birtakım bilgiler verildi (BCA, F.490.1.0.0/989.829.1/3/25-26/42/44/51/58). Kütahya ve Simav halkevleri tüm bu şubeleri aracıllğıyla yörede faaliyet gösteren okulların faaliyet alanı dişında kalan şehir halkına sanat, edebiyat ve spor eğitimi verdi.

\subsection{Maarif Vekâletinin Açtığ Çeşitli Kurslar}

Maarif Vekâleti özellikle yetişkinlere meslek veya çeşitli hünerler kazandırmak amacıyla belirli dönemlerde kurslar açmaktaydı. Kütahya ilinde açılan bu kurslara yönelik verilere maarif salnamelerinde sadece 1937-1938 eğitim öğretim y1lında değinilmekteydi. Bu dönemde Kur'an-1 Kerim öğretmek amacıyla bir kurs açıldı ve bu kursa 3'ü 17 yaşından küçük diğerleri yetişkin olmak üzere toplam 29 erkek kursiyer katıldı. Kursa katılanlardan 21'i millet mektebi mezunu ve 8’i de ilkokul mezunuydu (Maarif 1937-1938 İstatistiği, 1939: 242). Aynı yıl Simav ilçesinde Sıdıka Biçki Dikiş Yurdu tarafindan bir kurs açıldı. Bu kursa 2'si 18 yaşından küçük toplam 11 bayan kursiyer katıldı. Kursiyerlerin 6'sı ilkokul, 4'ü millet mektebi ve 1'i de orta dereceli okul mezunuydu (Maarif 1937-1938 Istatistiği, 1939: 250).

\subsection{Kütüphaneler}

Kütahya'da 1933-1934 ylları arasındaki verilere göre iki adet kütüphane mevcuttu. Maarif Vekâleti tarafindan kurulan Vahit Paşa Kütüphanesi ve bir şahsa ait olan Tavşanlı Zeytinoğlu Kütüphanesi. Her iki kütüphanenin birer erkek memuru bulunmaktaydı. Vahit Paşa Kütüphanesinin ayrıca bir de müstahdemi vardı. Bu kütüphanenin söz konusu dönemdeki yıllık masrafı memurların maaşlarıyla birlikte 738 lirayı bulmaktaydı (Maarif 1933-1934 Halk Okuma Odalar ve Umumî Kütüphaneler Istatistiği, 1935: 38).

Tablo No: 9 1933-1934 Yılları İtibarıla Kütahya'daki Mevcut Kütüphaneler ve Kitap Sayıları (Maarif 1933-1934 Halk. Okuma Odalarn ve Umumî Kütüphaneler İstatistiği, 1935: 44)

\begin{tabular}{|c|c|c|c|c|c|c|c|}
\hline \multirow{2}{*}{$\begin{array}{c}\text { Kütüphane } \\
\text { Adı }\end{array}$} & \multicolumn{3}{|c|}{ Türk Dilinde Yazılan } & \multicolumn{3}{c|}{ Yabancı Dillerde Yazılan } & Toplam \\
\cline { 2 - 7 } & Latin Harfleriyle & Arap Harfleriyle & Arapça & Farsça & Fransızca & İngilizce & Almanca \\
\hline
\end{tabular}




\begin{tabular}{|l|c|c|c|c|c|c|c|c|}
\hline $\begin{array}{l}\text { Vahit Paşa } \\
\text { Kütüphanesi }\end{array}$ & 923 & 946 & 1168 & 145 & 15 & - & 1 & 3198 \\
\hline $\begin{array}{l}\text { Tavssanlı } \\
\begin{array}{l}\text { Zeytinoğlu } \\
\text { Kütüphanesi }\end{array}\end{array}$ & 225 & 953 & 1470 & 272 & 5 & 4 & - & 2929 \\
\hline
\end{tabular}

Tablo No: 9'a göre; her iki kütüphanede toplam 6127 kitap bulunmaktaydı ve bu kitapların 1148'i (\%18,74’ü) Latin Harfleriyle yazılmış kitaplardan oluşmaktaydı ki bu oldukça yetersizdi. 1933-1934 yıllarında Vahit Paşa Kütüphanesine Maarif Vekâleti aracillğıyla 443 adet ve bağış olarak da 50 olmak üzere toplam 493 kitap kütüphaneye kazandırıldı. Tavşanlı Zeytinoğlu Kütüphanesine Maarif Vekâleti tarafından sadece 15 kitap bu dönemde ücretsiz olarak verildi.

Tablo No: 10 1933-1934 Y1lları İtibarryla Kütahya'daki Okul Kütüphanelerinde Bulunan Kitap Mevcutlar1 (Maarif 1933-1934 Halk. Okuma Odalar ve Umumî Kütüphaneler İstatistiği, 1935: 65)

\begin{tabular}{|c|c|c|c|c|c|c|c|c|}
\hline \multirow[b]{2}{*}{ Mahal } & \multirow{2}{*}{$\begin{array}{l}\text { Okul } \\
\text { Adedi }\end{array}$} & \multicolumn{3}{|c|}{ Türk Dilinde Yazılan } & \multicolumn{3}{|c|}{ Yabancı Dillerde Yazılan } & \multirow{2}{*}{$\begin{array}{c}\text { Genel } \\
\text { Toplam }\end{array}$} \\
\hline & & $\begin{array}{c}\text { Latin } \\
\text { Harfleriyle }\end{array}$ & $\begin{array}{c}\text { Arap } \\
\text { Harfleriyle }\end{array}$ & Top. & \begin{tabular}{|c} 
Doğu \\
Dilleriyle
\end{tabular} & $\begin{array}{l}\text { Diğer Yabanc1 } \\
\text { Dillerle }\end{array}$ & Top. & \\
\hline İl ve İlçe Merkezleri Okullar & 19 & 1178 & 1992 & 3170 & 14 & 29 & 43 & 3213 \\
\hline Köylerdeki Okullar & 116 & 2367 & 1297 & 3664 & 25 & - & 25 & 3689 \\
\hline Toplam & 135 & 3545 & 3289 & 6834 & 39 & 29 & 68 & 6902 \\
\hline
\end{tabular}

Tablo No: 10'a göre; tüm okullardaki Latin Harfleriyle yazılan kitap sayıs1 3545'di ve bu oran kütüphanelerdeki mevcut kitapların \%51,36'sını oluşturmaktaydı. Halk kütüphanelerine göre okul kütüphanelerinde \%32,62 oranında daha fazla Latin Harfleriyle yazılan kitap bulunmaktaydı.

1932-1933 eğitim öğretim y1lındaki verilere göre kütüphanelerden ağırlıklı olarak öğrenci, öğretmen ve memurlar yararlanmaktaydı (Maarif 1932-1933 Ístatistiği, 1934: 289).

\section{Sonuç}

Cumhuriyet Dönemi'nde Kütahya okuma-yazma açısından Türkiye ortalamalarının altında bulunmaktaydı. Bununla birlikte 1927-1935 yılları arası değerlendirildiğinde okuma-yazma oranındaki yaklaşık \%133,13'lük artısın yanında (erkeklerde \%96,72; kadınlarda \%349,55) kadınların okuma-yazma öğrenme oranındaki büyük ilerleyiş dikkat çekiciydi. İl genelindeki ilkokulların sayısındaki \%24,19 ve öğretmen sayısındaki \%10,88 artış okuma-yazma oranını yükseltti fakat dönem içinde uygulanan yasal zorunluluğa rağmen ebeveynlerin çocuklarını okula gönderme oranı \%22,9'da kaldı. Oranın bu kadar düşük olmasında bölge halkının eğitim öğretim faaliyetlerine yeterince ilgi göstermemesi ve çeşitli alanlarda faaliyet gösteren aile işletmelerinin sayıca fazla olması etkili oldu. Ayrıca şehrin ancak Atatürk döneminin sonlarına doğru bir liseye kavuşması, sadece Kütahya merkezde ve Uşak ilçe merkezinde birer anaokulu ve ortaokulun bulunması örgün öğretim kurumlarının il genelinde yetersiz kalmasına yol açtı. Nitekim 1932-1933 eğitim öğretim yılında il genelinde 154 okul vardı ve 1935 yılı nüfus sayımı verilerine göre bir okula düşen öğrenci sayısı yaklaşık 542'ydi.

Örgün ve yaygın eğitim öğretim kurumları ve bu okulların faaliyetleri açısından Kütahya merkez ve Uşak ilçesi ilin diğer yerleşim yerlerine oranla ilk sırada gelmekteydi. Okul çağında olmayan bölge halkının okuma-yazma öğrenmesinde bölgede açılan millet mekteplerinin düzenledikleri faaliyetler önemli derecede etkili oldu. Buna karşın kadınların okuma-yazma öğrenmesinde örgün öğretim kurumları ilk sırada yer aldı.

Kütahya Sanayi Zirai Yurdunun arıcılık, tavukçuluk, sütçülük ve konservecilik bölümleri bulunmaktaydı. Yurdun kendine ait bir matbaası vardı ve bu matbaada yurt görevlileri tarafindan Kütahya gazetesi basılmaktaydı. Gazetede okulun ifade edilen bölümlerine yönelik dönemin modern teknik usulleri anlatılarak öğrenciler akademik açıdan desteklenmeye çalışılmaktaydı. 


\section{KUMAŞ, Nursal (2021). “Atatürk Döneminde Kütahya'da Eğitim İstatistiklerinin Analizi”, Mavi Atlas, 9(1): 275-294}

Yaygın eğitim kurumları kapsamında değerlendirilen Türk Ocağının faaliyetleri hakkında fazla bir bilgiye ulașlamamasına karșın, șehrin merkezinde ve ilçe merkezlerinde ocağın șubelerinin bulunması nedeniyle bu kurumun özellikle konferanslar aracilığıla ilin eğitim faaliyetlerine bir şekilde katk1 yaptığ1 söylenebilir. Türk Ocağı şubelerinin kapatılıp bu kurumların yerini halkevlerinin almasıyla birlikte il genelinde de halkevleri açıldı. Kütahya ve Simav halkevlerinin halk dershaneleri ve kursları şubelerinin düzenledikleri faaliyetler önemli derecede etkili oldu. Halkevleri özellikle tiyatro, müzik ve spor branşlarında çeşitli eğitim faaliyetlerinde bulunarak bölge halkına yararlı olmaya çalıştı. Halkevinin ilgili şubesi tarafından kurulan bando ve salon orkestrasının vermiş olduğu ücretsiz konserler de bölge halkının müzik kültürünü geliştirmeye katkı yaptı. Yaygın eğitim kurumlarının görevi öncelikle halka okuma-yazma öğretmek ve sonra da halkın müzik dinlemesi, piyes izlemesi ve çeşitli spor faaliyetlerinde bulunmasını sağlamaktı. Bu faaliyetler örgün öğretim kurumlarında verilen dersler gibi olmasa da eğitimin bir parçasıydı. Halkevlerinin bir diğer görevi de çeşitli konular hakkında konferanslar vererek halkı bilgilendirmek ve genel kültür düzeylerini yükseltmekti. Bu amaçla şehirde faaliyet gösteren halkevleri pek çok konuda konferanslar verdi. Köycülük şubesi üyeleri köyleri dolaşarak bilginin ışığını kırsal alanlara taşıdılar. Halkevlerinin kendi bünyelerinde açtıkları kütüphanelere ek olarak şehir merkezinde açılan biri resmi diğeri özel iki kütüphanenin kitap sayısı dönem içinde sürekli bir artış gösterdi. Böylece bölge halkının kitaba ulaşması ve kitap sevgisi kazanmasında bu kurumlar önemli bir aracı rolü üstlendi.

Sonuç olarak bir taraftan şehirde mevcut anaokulu, ilkokul, ortaokul, lise ve mesleki liseler aracıllğıyla okul çağında olan nüfus eğitilirken diğer taraftan da Türk Ocağı, halkevleri, millet mektepleri, kütüphaneler ve yerel gazete aracıllı̆ıyla yetişkin halk eğitilmeye çalışıldı. Söz konusu çabalar yeterli olmasa da ülkenin içinde bulunduğu dönemin şartları dikkate alındığında bu açık bir başarıdyd.

\section{Kaynakça}

ARIKAN, Mustafa ve Ahmet DENIZ (2004). "Türk Ocaklarının Kapatılıșı, Borçları ve Emlâkinin Tasfiyesi”, Selçuk Üniversitesi Türkiyat Arașttrmalar Dergisi, 15: 401-432.

ÇETINTAŞ, Cengiz (2017). Kütabya Lisesi Mezunlar Hatura Defteri (1940-1990), ISBN: 978605-81170-8-2 (e-kitap).

DEĞERLİ, Esra Sarıkoyuncu ve Hasan YAPICI (2018). "Tek Parti Dönemi Kültür Kurumlarına Bir Örnek: Kütahya Halkevi”, Dumlupinar Üniversitesi Sosyal Bilimler Dergisi, 58: 1-14.

GÖKDÜL, Ali ve Ali SARIKOYUNCU (2017). "Kütahya Vilayet Gazetesi'ne Göre Kütahya Ticaret ve Sanayi Odas1 (1925-1944)”, Dumlupınar Üniversitesi Sosyal Bilimler Dergisi, 52: 103122.

DERETARLA GÜL, Ebru (2008). "Meşrutiyet’ten Günümüze Okul Öncesi Eğitim”, Çukurova Üniversitesi Sosyal Bilimler Enstitüsü Dergisi, 17(1), 269-278.

HAVANUR, Şahin, (2010). Kütahya Halkevi'nin Kuruluşu ve Faaliyetleri (1932-1937), (Yayımlanmamış Yüksek Lisans Tezi), Kütahya: Dumlupınar Üniversitesi Sosyal Bilimler Enstitüsü.

KAÇMAZ, Ekrem (2010). Kütahya Lisesi ve Tarihi Gelişimi, (Yayımlanmamış Yüksek Lisans Tezi), Konya: Selçuk Üniversitesi Eğitim Bilimleri Enstitüsü.

KARADUMAN, Hüseyin (2007), “Türk Ocakları ve Hars Müzeleri”, Vakifflar Dergisi, XXX, 503-518.

KEPECİĞLU, Kâmil (2009). Bursa Kütï̈̆̈̈, haz. Hüseyin Algül, Osman Çetin, Mefail Hızlı, Mustafa Kara ve Asım Yediyıldız, Cilt I-IV, Bursa: Bursa Büyükşehir Belediyesi Yayınları. 
KODAMAN, Bayram (1991). Abdülhamid Devri Ë̆itim Sistemi, Ankara: Atatürk Kültür, Dil ve Tarih Yüksek Kurumu Türk Tarih Kurumu Yayınları. 580-584.

VARLIK, Mustafa Çetin (2002). "Kütahya", Türkiye Diyanet Vakfi İlam Ansiklopedisi, 26,

YETKIN, Osman; ABAȘ, Kamil; GÜVEN, Mustafa; BERBEROĞLU Mehmet; GÜL, Şakir; BİNTEPE, Yaşar ve Metin UMAÇ (1998), Kütabya İli Cumburiyet Öncesi ve Sonrası Eğitim, Kütahya: Ekspres Matbaası.

YILDIRIM, Harun (2017). 1925-1928 Y1llar1 Aras1 Türkiye Cumhuriyeti Salnameleri (Kütahya), (Yayımlanmamış Yüksek Lisans Tezi). Kütahya: Dumlupınar Üniversitesi Sosyal Bilimler Enstitüsü.

\section{Diğger Kaynaklar}

CHF Halkevleri Talimatnamesi (1932). Hâkimiyeti Milliye Matbaasi.

Halk Okuma Odalar Rebberi (1929). Ankara: T.C. Maarif Vekâleti.

Hudâvendigâr Vilâyeti Sâlnâme-i Resmîsi (1316). Defa 25. Bursa: Matbaa-i Vilâyet.

Hudâvendigâr Vilâyeti Sâlnâme-i Resmîsi (1321). Defa 30. Bursa: Matbaa-i Vilâyet.

Hudâvendigâr Vilâyeti Sâlnâme-i Resmîsi (1325). Defa 34. Bursa: Matbaa-i Vilâyet.

Kanunlar Dergisi (2 Haziran 1926). Kanun No: 842, C.4.

Kütabya, S. 1, 1 Aralık 1925; S. 69, 15 Ekim 1928.

Maârif 1923-1932 İstatistikleri (1933). Başvekâlet İstatistik Umum Müdürlüğü, No: 26, İstanbul: Devlet Matbaası.

Maarif 1928-1933 Millet Mektepleri Faaliyeti İstatistiği (1934). Başvekâlet İstatistik Umum Müdürlügü, Neşriyat No: 28, İstanbul: Devlet Matbaas1.

Maârif1932-1933 İstatistiği (1934). No: 31, Başvekâlet İstatistik Umum Müdürlüğü, İstanbul: Devlet Matbaasi.

Maarif 1937-1938 İstatistiğ (1939). No: 145, İstanbul: Sühulet Basımevi.

Maarif 1928-1934 Millet Mektepleri Faaliyeti İstatistiği (1934). Başvekâlet İstatistik Umum Müdürlügü, Neşriyat No: 51, İstanbul: Devlet Matbaas1.

Maarif 1928-1935 Millet Mektepleri Faaliyeti İstatistiği (1935). Başvekâlet İstatistik Umum Müdürlüğü, Neşriyat No: 72, İstanbul: Hüsnütabiat Matbaas1.

Maarif 1933-1934 Halk Okuma Odalar ve Umumî Kütüphaneler İstatistiği (1935). Başvekâlet İstatistik Umum Müdürlüğü, Neşriyat No: 60, İstanbul: Devlet Matbaas1.

Millet Mektepleri Talimatnamesi ve Tatbikine Rehberlik Edecek Dâbili Talimatnameler (1929). Ankara: Köy Hocası Matbaas1.

Sanayi Sayımı 1927 (1969). Başbakanlık Devlet İstatistik Enstitüsü, Yayın No: 584, Ankara: Devlet İstatistik Enstitüsü Matbaası.

Türkiye Cumburiyeti Devlet Sâlnâmesi (Rüsumat Sâlnâmesi) 1925-1926, (1926). İstanbul: İstanbul Matbaasi.

Türkiye Cumburiyeti Devlet Sâlnâmesi (Rüsumat Sâlnâmesi) 1926-1927, (1927). Matbuat Müdüriyet Umumiyesi Neşriyatı: 2.

Türkiye Cumburiyeti Devlet Sâlnâmesi (Rüsumat Sâlnâmesi) 1927-1928, (1928). Matbuat Müdüriyet Umumiyesi Neşriyat1: 3.

T. C. Maarif Vekâleti 1926-1927 İstatistik Yullĭg (1929). C. 4, İstanbul: Devlet Matbaası. 
KUMAŞ, Nursal (2021). “Atatürk Döneminde Kütahya'da Eğitim İstatistiklerinin Analizi”, Mavi Atlas, 9(1): 275-294

28 Teşrinievvel 1927 Umumî Nüfus Tahriri Mufassal Neticeler (1929). Türkiye Cumhuriyeti Başvekâlet İstatistik Umum Müdürlüğü, Fasikül I, Ankara: Hüsnütabiat Matbaası.

28 Teşrinievvel 1927 Umumî Nüfus Tabriri Usuller Kanun ve Talimatnameler Neticelerin Tablili (1929). Fasikül III, Ankara: Başvekâlet Müdevvenat Matbaası.

20 İlktessrin 1935 Genel Nüfus Sayım Kat’̂̀ ve Mufassal Neticeler (1937). Türkiye Cumhuriyeti Başbakanlık İstatistik Genel Direktörlüğü, C. 60, Ankara: Mehmet İhsan Basımevi.

20 İlketeşrin 1935 Genel Nüfus Sayım Kat’̂ ve Mufassal Neticeler Kütabya Vilâyeti (1937). Türkiye Cumhuriyeti Başbakanlık İstatistik Genel Direktörlüğü, C. 38, İstanbul: Devlet Basımevi.

1339-1340 İbsâiyat Mecmuası (1341). İstanbul.

1924-1925 İhsâiyat Mecmuasz (1927). İstanbul.

\section{Devlet Arşivleri Başkanlığ1 Cumhuriyet Arşivi (BCA)}

F.490.1.0.0/989.829.1/1-4/42-44/51-53/58, (1 Şubat 1938) (Kütahya Halkevi).

F.490.1.0.0/989.829.1/24-27/29, (1 Şubat 1938) (Simav Halkevi).

F.490.1.0.0/69.260.1/26/36/48/83/136, (7 Ekim 1938) (Türk Ocağ1).

F.490.1.0.0/1.2.13/1, 25 Aralık 1928; F.490.1.0.0/1.3.12/6-54, (28 Ekim 1929) (Millet Mektepleri). 